DCN 83-212-011-62

DOE/SF/11503-2

(DE84004539)

Distribution Category UC-66d

\title{
REVIEW OF SHELL-AND-TUBE HEAT EXCHANGER FOULING AND CORROSION IN GEOTHERMAL POWER PLANT SERVICE
}

Topical Report

15

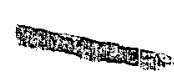

Prepared by

Peter F. E11 is II

Radian Corporation

Austin, Texas

Prepared for

UNITED STATES DEPARTMENT OF ENERGY

Fossil, Geotherma1, and Solar Energy Division

Oakland, California 94612

under

DOE Contract DE-AC03-81SF11503

December 1983 


\section{DISCLAIMER}

This report was prepared as an account of work sponsored by an agency of the United States Government. Neither the United States Government nor any agency Thereof, nor any of their employees, makes any warranty, express or implied, or assumes any legal liability or responsibility for the accuracy, completeness, or usefulness of any information, apparatus, product, or process disclosed, or represents that its use would not infringe privately owned rights. Reference herein to any specific commercial product, process, or service by trade name, trademark, manufacturer, or otherwise does not necessarily constitute or imply its endorsement, recommendation, or favoring by the United States Government or any agency thereof. The views and opinions of authors expressed herein do not necessarily state or reflect those of the United States Government or any agency thereof. 


\section{DISCLAIMER}

Portions of this document may be illegible in electronic image products. Images are produced from the best available original document. 


\section{CONTENTS}

Section

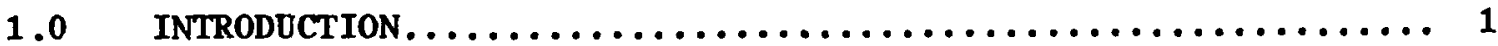

$1.1 \quad$ Scope.................................... 3

1.2 Overview............................... 3

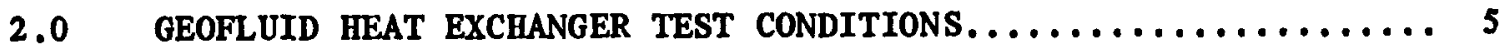

2.1 East Mesa.............................. s

2.1.1 Supercritical Heat Exchanger Field Test (SHEFT). 5

2.1.2 Simulated Heat Exchanger Tube Corrosion Test.... 10

2.1.3 Magma 10MW Geothermal Binary P1ant.......... 12

$2.2 \quad$ Heber.................................... 14

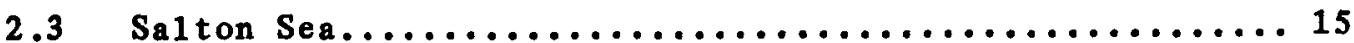

2.4 Svartsengi and Hveragerdi, Iceland.............. 18

3.0 FOULING OF POWER PLANT GEOFLUID HEAT EXCHANGERS .......... 21

3.1 Overview of Fouling Factor Data................ 21

3.2 Results of Individual Trials.................. 28

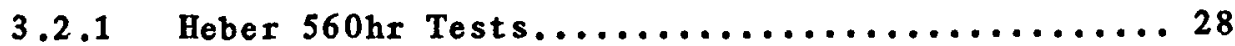

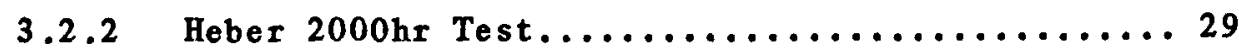

3.2 .3 Sa1ton Sea Test...................... 31

3.2.4 Tests at Svartsengi and Hveragerdi.......... 31

4.0 CORROSION OF POWER PLANT GEOFLUID HEAT EXCHANGERS......... 35

4.1 Heber................................... 36

4.2 East Mesa............................... 38

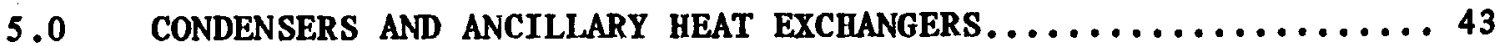

5.1 Geothermal Steam Power P1ants................... 44

5.2 Geotherma1 Binary P1ants.................... 50

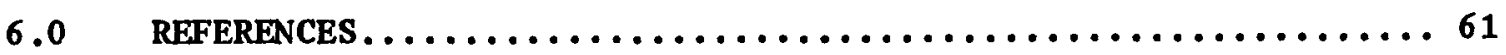




\section{LIST OF FIGURES}

E1gure

Pase

$2-1$

Schematic Diagram of the Supercritical Heat Exchanger

Field Test (SHEFT) Facility..................

8

2-2 F1ow Chart of the Magma 10MN Geothermal Binary

P1ant................................

3-1 Time Dependence of Fonling Factor for a Number of Geotherma1 Heat Exchangers....................

Chloride Required to Produce Localized Corrosion of Type 304 and Type 316 s a Function of Temperature...

Effect of $\mathrm{pH}$, Chloride Content, and Temperature of the Stress Corrosion Cracking of Typo 304 Stainless Steel under Residual Weld Stresses................... 


\section{LIST OF TABLES}

$\underline{T a b 1 e}$

Page

2-1 Chemistry of Mesa 6-2 Geofluid and the Geofluid

Supply of the Magma 10MW Binary Power Plant.........

Sheft Heat Exchanger Details..................

Physical Corrosion Test Conditions During the

Simulated Heat Exchanger....................

2-4 Chemistry of Now1in No. 1 Geofluid as Measured During

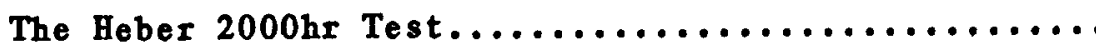

Representative Chemistry of Flashed Geofluid From

Magmamax No. 1..........................

2-6 Compositions of Geothermal Vaters Used in the

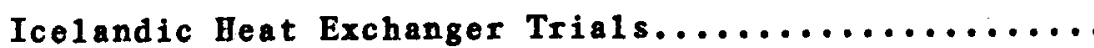

3-1 Overview of Powerplant Geofluid Heat Exchanger

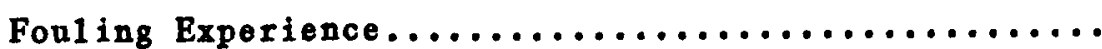

Examples of Cooling Water Chemistry from Geothermal

Power Plants Using Steam Condensate Without Hydrogen

Sulfide Abatement as Cooling Tater Makenp.......... 


\section{LIST OF TABLES (Continued)}

$\underline{\text { Tab1e }}$

Page

5-2

Summary of Final Water Treatment for the Raft River

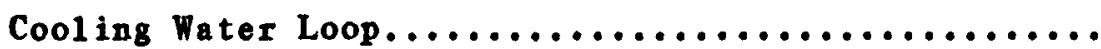

$5-3$

Typical Analysis of the Circulating Water in Pilot

Cooling Tower Corrosion Tests..................

$5-4$

Results of the Pilot Cooling Tower Tests at Raft

River, ID

Typical IID Irrigation Water Chemistry........... 


\section{EXECUTIVE SUMMARY}

She11-and-tube heat exchangers will 1ikely represent some of the most costly components of geothermal binary (organic Rankine) cycle and future geothermal steam power plants. These exchangers will be used as condensers in most future geothermal steam power plants, as secondary working substance vaporizers and condensers in binary plants, and for numerous other ancillary services in both types of plants.

The costly nature of these shell-and-tube exchangers is due to: 1) the 1 arge size requirements compared to conventional fossil-fired power p1ants, 2) the requirements for corrosion resistant alloys to resist the generally aggressive waters utilized, and 3 ) the frequent requirement for an extremely high level of integrity.

The 1 arge size is important from a corrosion standpoint because the probable time to failure by pitting decreases exponentially with increased surface area. Thus, large components will fail more rapidly by pitting than smaller ones. Additionally, thin tube walls are desired for high heat transfer, but thin walls al so reduce the time to corrosion related failure.

Despite the 1 imited amount of corrosion data available from geothermal power plant heat exchangers and test simulations, some conclusions can be reached. At the resources of near-term interest for binary power plant development--East Mesa, Heber, Raft River--uniform corrosion rates on the order of 3-7 mpy (mil/yr) can be expected for carbon steel. However, even under conditions which appear to rigorously exclude oxygen, carbon steel pitting rates of up to 46 mpy have been observed. Some or all of these geofluids can cause pitting of carbon steel even in the absence of oxygen. In addition, both uniform corrosion and pitting of carbon steel heat exchanger tubes are greatly accelerated by even traces of oxygen introduced during shutdown. The rigorous and complete exclusion of oxygen from large heat exchangers at all times, whether or not the system is operating, appears to present tremendous 
practical problems. For these reasons, it is concluded that carbon steel will not be viable in many cases as a geothermal power plant heat exchanger tube material unless frequent retubing is planned.

It appears therefore that heat exchanger tube alloys capable of resisting both normal operating conditions and aerated geofluid are likely to be required. Currently the prime candidates appear to be Allegheny-Ludlum Alloys 29-4 and 29-4C (29Cr-4Mo ferritic stainless steels) and TiCode 12 (a titanium alloy). Other alloys such as SeaCure 26-3 and E-brite 26-1 have not been tested under conditions simulating geothermal binary evaporator service, but may al so be shown to be of some usefulness after testing. Selection between the $29 \mathrm{Cr}-4$ Mo alloys and the titanium alloy is 1 ikely to be dictated by economic factors since their corrosion performance is 1 ikely to be comparable under most conditions.

The experience to date has indicated three major foulants of geofluid/working fluid heat exchangers: corrosion products, calcium carbonate, and silica. Experience at Heber has shown that the fouling of carbon steel tubes (which corrode in Heber geofluid) was three to five times greater than the fouling of titanium tubes (which do not corrode in this environment). Use of highly corrosion resistant tubing is clearly a key to fouling control.

At East Mesa and Heber calcium carbonate scaling is a major concern. It has been shown that maintaining geofluid pressure to keep the carbon dioxide in solution prevents significant deposition of calcium carbonate. Available data indicate that if the goofluid pressure is maintained, then heat exchanger operation with annual cleaning is feasible.

Silica fouling can occur when geofluid from high temperature resources is cooled below the silica saturation temperature. In cases where this occurs fouling is more rapid. In addition, silica scale is particularly difficult to remove. 
The condensers and ancillary cooling loop heat exchangers of geothermal binary power plants face severe materials problems since most p1ants will be located in arid or semi-arid regions where vigorous competition for wateruse rights is 1 ikely. These plants are likely to be forced to use poor quality water for cooling water make-up. Water treatments designed to protect carbon steel have not been satisfactory because the system is made inherently sensitive to control upsets which would force several-week-1ong shutdowns for cleaning and repassivation of the condenser. Fouling control has al so not been demonstrated.

Based on experience to date, highly alloyed ferritic stainless steels (such as Allegheny-Ludlum 29-4, 29-4-2, and 29-4C, and SeaCure 26-3) and titanium appear to be prime candidates for this application.

She11-and-tube heat exchangers in the cooling loop of geothermal steam power plants are also subject to corrosion, and Type 304 stainless steel has shown to be problematical as tubing in this service. The corrosivity of the geothermal steam condensate/cooling water is increased by action of su1fide oxidizing bacteria and chemical additives such as ferric ion and hydrogen peroxide added for primary or secondary abatement of hydrogen sulfide. Type 316 may have adequate pitting resistance, but stress corrosion cracking may also be a factor, particularly if high temperature steam is vented to the condenser during turbine trips. The highly alloyed ferritic stainless steels discussed above may be desirable and cost effective. 
She11-and-tube heat exchangers--both working fluid vaporizers and condensers--will represent the most costly components of most geothermal binary power plants. In addition, hydrogen sulfide abatement technology at The Geyers requires that some current and all future units operate with surface contact condensers. The same constraint is likely in flashed-steam plants at other sites as we11. At The Geysers, these condensers are she11-andtube. Because of the huge heat rejection loads of geothermal plants, these she11-and-tube condensers are quite large. Finally, regardless of the power cycle and type of condenser used, all geothermal power plants employ a number of ancillary heat exchangers in the cooling water loop to allow for heat rejection from 1 ubricating oil, generator coolant (hydrogen), and possibly other service streams. In geothermal steam power plants, materials problems will be exacerbated by chemicals such as ferric sulfate and hydrogen peroxide added for hydrogen sulfide abatement. These chemicals increase corrosivity. Many geothermal binary plants will have to use very poor quality cooling water, leading to severe materials constraints to avoid corrosion.

The she11-and-tube heat exchangers used in geothermal power plants have a number of inherent characteristics which make them particularly susceptible to corrosion failure. The first of these factors is size. For example, the tubes of the isobutane vaporizers at the Magma Binary Power Plant (East Mesa) have a mean surface area of $25,325 \mathrm{ft}^{2}$, or $2,025 \mathrm{ft}^{2} / \mathrm{GMW}$ (gross megawatt). The tubes of the she11-and-tube condenser of the Raft River Binary Power Plant have a total surface area of approximately $57,000 \mathrm{ft}^{2}$, or 7,600 $\mathrm{ft}^{2} / \mathrm{GMW}$. This large size is important from a corrosion standpoint because the probable time to failure by pitting-if this corrosion mode occurs--decreases exponentially with increasing area. This means that large components will fail much more rapidly by pitting than will smaller ones, all other factors being equa 1 . 
The socond major factor contributing to the corrosion vulnerability of geothermal power plant heat exchangers is the thinness of the tube walls. The thinnest possible walls are desired to maximize heat transfer.

The third factor contributing to vulnerability is the minimum acceptable integrity of the heat exchangers. Some leakage is probably acceptable in shel1-and-tube surface condensers in geothermal steam (Rankine and flashedsteam cycle) power plants, since such leakage would impair hydrogen sulfide abetement, but would not endanger plant equipment. On the other hand, the working substance (probably light hydrocarbon) vaporizers and condensers of a geothermal binary plant, as well as the generator hydrogen coolers of large power plants, require complete leak-tight integrity to prevent release of gaseous--and potentially flammable or explosive--working substance. The high degree of leak-tight integrity of both the binary cycle vaporizer and condenser is also important to prevent corrosive geothermal finid from contacting binary loop components which are not intended for such exposure. Radian has analyzed several binary loop component failures which were due-at least in part--to such contamination. These are discussed in a separate publication, the Addendum to Materials Selection Guidelines for Geothermal Energy Utilizgtion Systems [Smith and E11 is 1983].

Thus, the fact that geothermal power plant heat exchangers are 1ikely to be she11-and-tube devices with extremely large surface areas of thin walled tubing, requiring virtually nil cross-leakage, makes them major materials selection problem, as well as a potential cause of forced outage and prolonged shut-down. This explains why carbon steel will in many cases not be viable as geothermal power plant heat exchanger tube material unless frequent retubing is planned.

Fouling (deposition) in the heat exchangers will also have a significant impact on plant design and economics. Current experience indicates that material selection is one factor determining the fouling tendencies of geo- 
thermal binary heat exchangers. Also, selection of antifouling measures (such as maintaining dissolved carbon dioxide pressure) may significantly alter materials performances, requiring alternate materials selections.

\section{$1.1 \quad$ Scope}

This topical report is a review of experience gained to date in the corrosion and fouling of heat exchangers used in geothermal power plants. This report considers only the geofluid or cooling water side--usually the tubeside--of these heat exchangers. With one exception, all of the tests described involved actual heat exchangers, and all were conducted using actual. geothermal fluids rather than synthetic laboratory solutions.

The broader subject of geothermal materials selection has been considered in depth by Radian in three major reports for the Department of Energy. These reports are:

- Materials Selection Guidelines For Geothermal Energy Utilization Systems, NTIS Pub. Code DOE/RA/27026-1, January 1981 .

- Addendum to Materials Selection Guidelines For Geotherma1 Energy Utilization Systems, NTIS Pub. Code DOE/RA/27026-2, May 1983 .

- Corrosion Reference For Geotherma1 Downhole Materials Selection, NTIS Pub. Code DOE/SF/11503-1, March 1983.

The first two documents are concerned primarily with corrosion of above ground components, while the third pertains to geothermal wells and tho components which are used downhole.

\subsection{Oxerview}

Heat exchangers for hot geofluid/working substance vaporizers for binary power plants are considered in Sections 2,3 , and 4 . A brief description of the physical test apparatus and the geofluid chemistry for each of the 
several heat exchanger tests is presented in Section 2 . Section 3 summarizes the fouling data developed from these tests, in most cases presenting a mathematical expression for the increase in fouling factor with time. Section 4 explores the materials performance data developed from these same tests. This organizational approach serves to concentrate the results into two distinct sections, undiluted by discussions of test method.

Section 5 considers the performance of she11-and-tube heat exchangers used as condensers and ancillary coolers in the power plant heat rejection system. 
This section presents a brief description of the physical apparatus and operating conditions for a number of geofluid heat exchanger experiences at five resources: East Mesa, lleber, and Salton Sea (California), and Svartsengi and Hveragerdi (Iceland). The fouling results are presented in Section 3 and the corrosion results are in Section 4.

\section{$2.1 \quad$ East Mesa}

Three experiences at East Mesa are considered, a scale model test of geofluid/hydrocarbon evaporators and condensers, a corrosion test of two highly alloyed ferritic stainless steels, and two years of operating experience at the Magma Power Company's $10 \mathrm{MW}$ binary plant.

The two tests were performed using geof 1 uid produced by a downwell pump from wel1 Mesa 6-2, while the Magma plant was supplied with pumped pressurized geofluid from five wells. Calcium carbonate scaling is a major problem at this resource if the geofluid is allowed to flash, evolving carbon dioxide. Therefore, the geofluid pressure was maintained above the gas breakout pressure throughout the tests to prevent calcium carbonate precipitation. Table 2-1 presents a summary of the corrosive and scaling chemistry of the unf1ashed Mesa 6-2 geofluid and of the Magma Power P1ant geof1uid supply.

\subsubsection{Supercritical Heat Exchanger Fie1d Test (SHEFT)}

In order to obtain performance data to support design of a 1 arge (50 MW) geothermal binary power plant, a $1: 100$ scale mode 1 test 100 was constructed at the DOE Geothermal Test Facility (GTF) at East Mesa, and tests were conducted from June 1980 through March 1981. The primary objective of the testing was measurement of supercritical performance of geofluid/hydrocarbon heat exchangers with three secondary working fluids: commercial isobutane, $90 / 10$ i sobutane/i sopentane, and $80 / 20$ isobutane/isopentane. 
TABLE 2-1. CHEMISTRY OF MESA 6-2 GEOFLUID AND THE GEOFLUID SUPPLY OF THE MAGMA 10MW BINARY POWER PLANT

\begin{tabular}{|c|c|c|}
\hline \multirow[b]{2}{*}{ Component } & \multicolumn{2}{|c|}{ Concentration (ppm except $\mathrm{pH}$ ) } \\
\hline & Mesa $6-2^{a}$ & Magma b \\
\hline pH & 6.15 & $5.2-5.9$ \\
\hline Ch1oride & 2150 & $3680-6270$ \\
\hline Sulfate & 113 & $68-86$ \\
\hline Bicarbonate & 580 & $216-367$ \\
\hline Carbon Dioxide (Total) & 2230 & $1580-2090$ \\
\hline Hydrogen Sulfide & 0.91 & $0.7-1.6$ \\
\hline Ammonia & $<0.02$ & $14-23$ \\
\hline Silica & 209 & $201-278$ \\
\hline Ca1cium & 16 & $20-81$ \\
\hline Magnesi um & 1.3 & $0.3-2.9$ \\
\hline
\end{tabular}

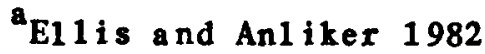

bhannon et al 1981 
The test $100 p$ is shown schematically in Figure 2-1. The unit consisted of three fluid loops: geofluid, hydrocarbon, and cooling water. The three loops were interconnected through the primary geofluid/hydrocarbon heat exchanger train and condenser/subcooler train. The heat load was rejected to the atmosphere through a wet cooling tower. The high pressure (heater) portion of the hydrocarbon loop was separated from the low-pressure (condenser) portion by an expansion valve in lieu of a turbine.

The primary geofluid/hydrocarbon heat exchanger train consisted of six exchangers, both sides in series, with brine in the tubes and hydrocarbon in the shells. The primary heat exchangers are labeled B-1 through B-6 in Figure 2-1. Table 2-2 1 ists the main features of the exchangers. Exchangers B-1 through B-5 were identical; exchanger B-6 had double-segmented baffles with all other specifications as 1 isted in Table 2-2.

Unflashed pressurized brine entered B-6, B-5, or B-4 depending on the operation of the inlet valving. The exchangers B-4 through B-6 spanned the near-critical region. The brine valving connecting these exchangers to the brine supply allowed the temperature-pressure profile of the heating curve to be adjusted so that data would be more readily obtained throughout the nearcritical region. Spent brine exited B-1 then flowed to the GTF silencer where it was flashed to the atmosphere.

Superheated hydrocarbon exited B-6, flowed through the pressurereducing valve, then entered the condenser. The condenser was a two-pass unit with vertical pass 1 anes and external valving that allowed the tubo bundle to be halved. Table 2-2 also 1 ists the main features of the condenser. The condensed hydrocarbon was further cooled by the subcooler to about $120 \mathrm{~F}$, then entered the hydrocarbon feed pump, $P-1$, where it was pressurized to supercritical pressure and discharged into B-1 to be heated upon passage to the exit of B-6. Cooling water for the condenser/subcooler was supplied by the GTF cooling tower [Silvester and Doyle 1982]. 


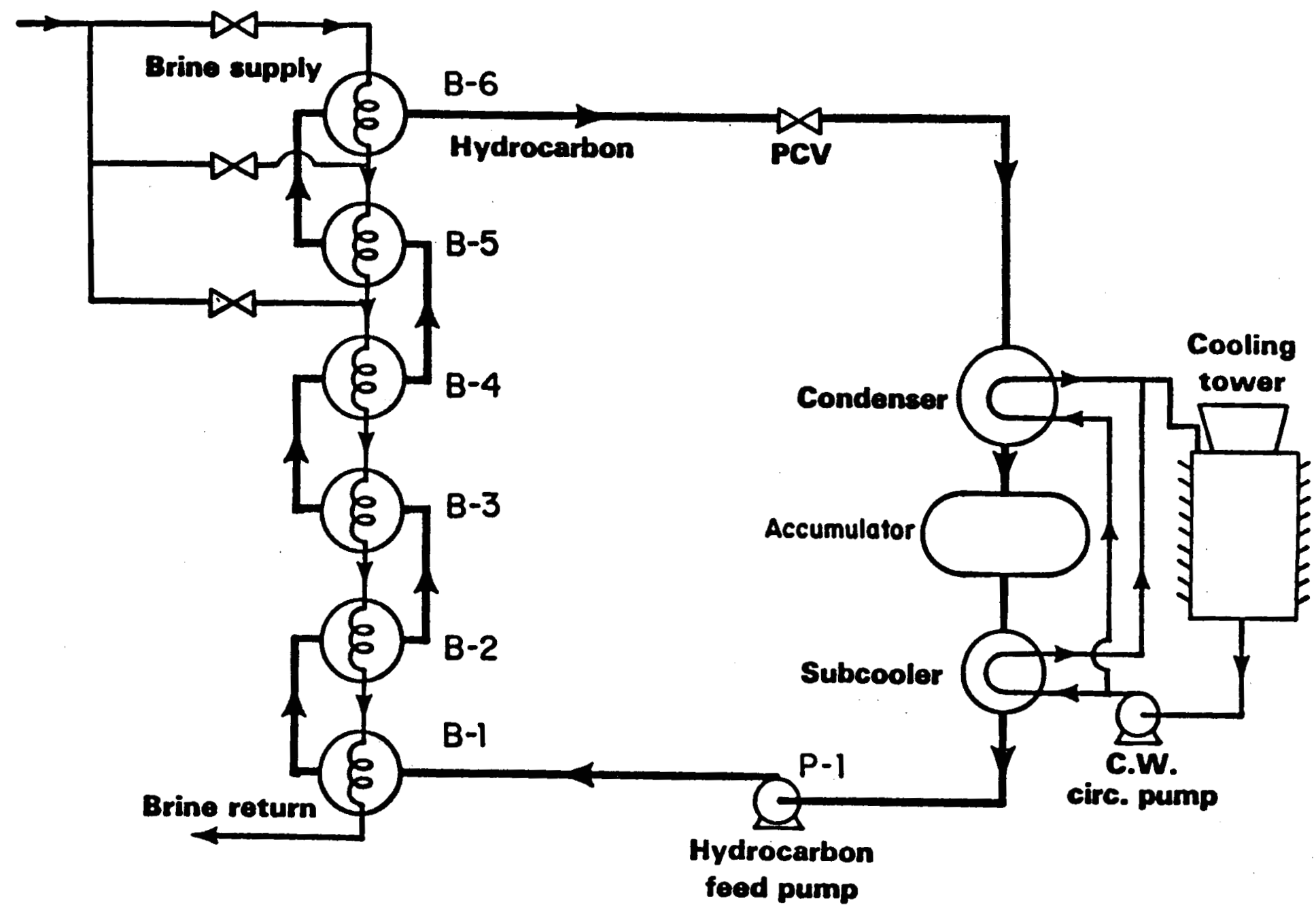

Figure 2-1. Schematic Diagram of the Supercritical Heat Exchanger Field Test (SHEFT) Facility [Silvester and Doyle 1982] 


\section{Hydrocarbon Heaters}

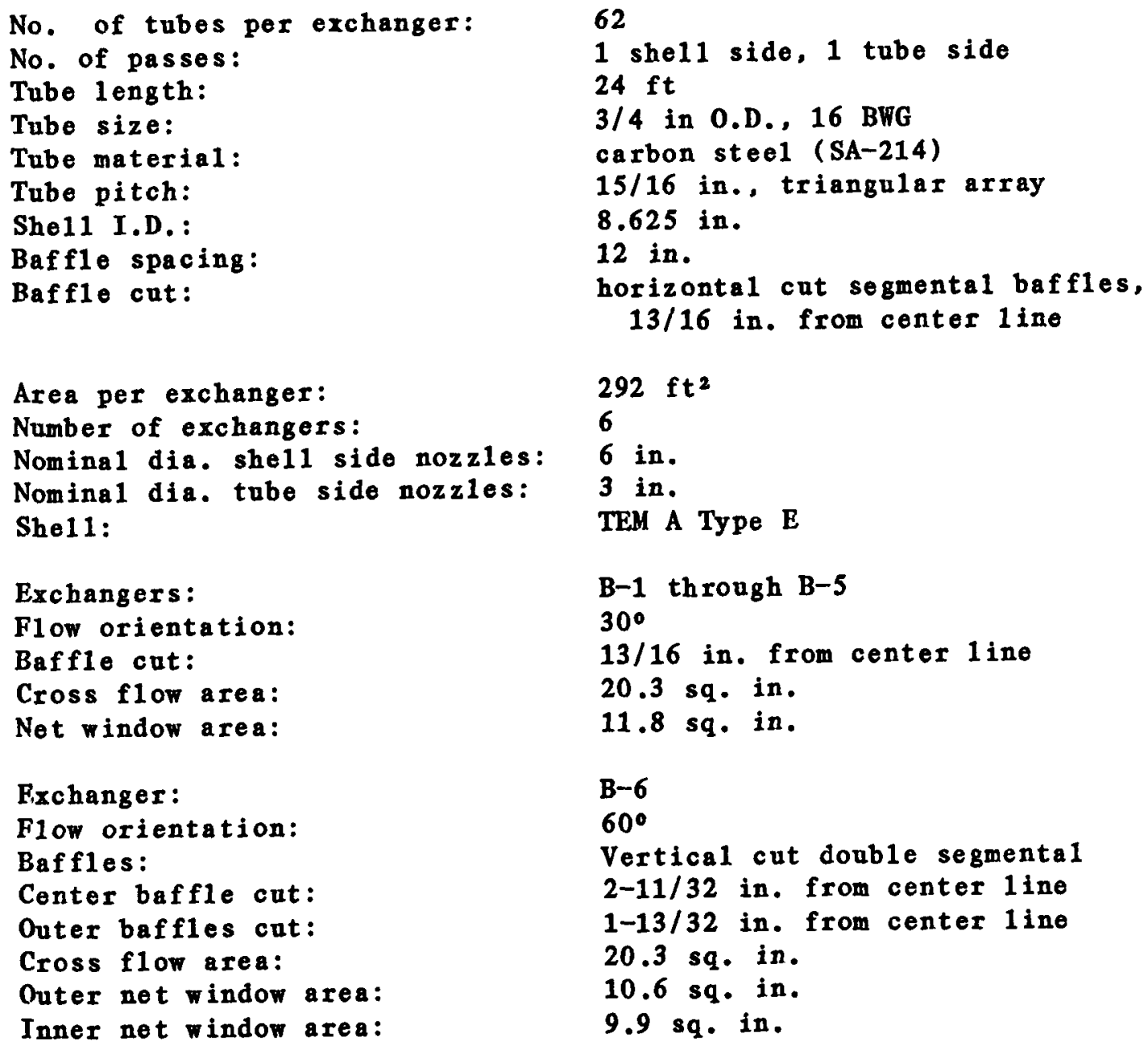

\section{Condenser}

No. of tubes:

No. of passes:

Tube 1 ength:

Tube size:

Tube material:

Tube pitch:

She11 I.D.:

Baffies:
332

1 she11 side, 1 tube side

$24 \mathrm{ft}$

$3 / 4$ in. O.D., 14 BWG

carbon steel (SA-214)

$15 / 16$ in., triangular array

22 in.

supports

${ }^{a}$ Side by side

Source: Silvester and Doyle 1982 
All hed exchangers and piping were chemically cleaned prior to testing, and the hydrocarbon working substance was continuously filtered to remove particulates 1 arger than 0.5 micrometer in size.

\subsubsection{Simylated Heat Exchanger Tube Corrosion Test}

Specimens of two metals, Allegheny-Ludlum A1loy 29-4 and 29-4C, were exposed at the GTF under conditions simulating flow in a geothermal heat exchanger tube [E11 is and An1iker 1982]. The chemistry of the geofluid used, as determined during the test, is given in Table 2-1. The specinens were short lengths of welded tubing. They were electrically isolated and supported by machined Teflon sleeves. The bores of the specimens and the sleeves formed a smooth tube; the exterior surfaces of the specimens were completely covered by the sleeves. "Strings" of 18 specimens, nine of each alloy, were Inserted into flanged steel pipe holders and compressed between the flanges. These flanges connected to the geofluid supply and discharge. The test apparatus was so designed that the interior surface was exposed to flowing geofluid at 1.2 to $5.4 \mathrm{ft} / \mathrm{sec}$ while the exterior surface was exposed to the stagnant geofluid which became trapped in the tight crevices between the specimens and the Teflon sleeves. Nine specimens of each alloy were exposed to each of two separate environments. This number of specimens allowed a statistical evaluation of resultant corrosion data.

One section of specimens was exposed to $349.5^{\circ} \mathrm{F}$ geofluid for 1032.25 hours. There were two shutdown periods, one of 15 minutes and one of 45 hours. During the 45-hour shutdown the section was isolated by valves. The other section, exposed to $349.5^{\circ} \mathrm{F}$ geofluid, was al so subjected to 12 simulated shutdown cycles. The average cycle consisted of 25.4 hours exposure to flowing geofluid, followed by a 4.2-hour pressurized cooldown period, followed by 56.2 hours in which the chamber was open to the air and the specimens were partially filled with geofluid.

Table 2-3 presents a summary of the physical test conditions. 
TABLE 2-3 . PHYSICAL CORROSION TEST CONDITIONS DURING THE SIMULATED HEAT EXCHANGER

\begin{tabular}{|c|c|c|c|c|c|c|}
\hline \multirow[b]{2}{*}{ Envi ronment } & & \multirow{2}{*}{$\begin{array}{l}\text { Temp. } \\
(0 F)\end{array}$} & \multirow{2}{*}{$\begin{array}{l}\text { Pressure } \\
\text { (psi) }\end{array}$} & \multirow{2}{*}{$\begin{array}{l}\text { F1 ow } \\
(\text { gpm) }\end{array}$} & \multicolumn{2}{|c|}{$\begin{array}{l}\text { Velocity (fps) } \\
\text { Through Coupons }\end{array}$} \\
\hline & & & & & $29-4$ & $29-4 \mathrm{C}$ \\
\hline Continuous Flow Test & min & 330 & 247 & 3.49 & 1.9 & 1.2 \\
\hline $1032.25 \mathrm{hrs}$ & $\max$ & $\begin{array}{l}350 \\
349.5^{b}\end{array}$ & $\begin{array}{l}375 \\
293^{c}\end{array}$ & $\begin{array}{c}10.02 \\
6.6\end{array}$ & $\begin{array}{l}5.4 \\
3.5\end{array}$ & $\begin{array}{l}3.5 \\
2.3\end{array}$ \\
\hline \multicolumn{7}{|l|}{$\frac{\text { Cyclic Exposure Test }}{\text { Per Cyc1 }}$} \\
\hline F1 ow $=25.4 \mathrm{hrs}$ & $\begin{array}{l}\min \\
\max \\
\text { avg }\end{array}$ & $\begin{array}{l}330 \\
350 \\
349.5\end{array}$ & $\begin{array}{l}247 \\
375 \\
293\end{array}$ & $\begin{array}{r}3.49 \\
10.02 \\
6.8^{d}\end{array}$ & $\begin{array}{l}1.9 \\
5.4 \\
3.6\end{array}$ & $\begin{array}{l}1.2 \\
3.5 \\
2.4\end{array}$ \\
\hline Coo1down $=4.2 \mathrm{hrs}$ & \multicolumn{6}{|c|}{$\begin{array}{l}\text { Chamber cooled under pressure to near ambient } \\
\text { temperature. }\end{array}$} \\
\hline Open $=56.2 \mathrm{hrs}$ & \multicolumn{6}{|c|}{$\begin{array}{l}\text { Chamber opened to air. Geofluid partially filled } \\
\text { the tubular corrosion specimens. }\end{array}$} \\
\hline
\end{tabular}

\footnotetext{
aypical cycle. Twelve such cycles occurred, with some variation in length in each of the stages.

${ }^{b 5}$ data points.

c 81 data points.

$\mathrm{d}_{34}$ data points.

Source: E11is and Anliker 1982
} 


\section{1 .3 Magma 10MW Geothermal Binary P1ant}

Figure 2-2 is a flowchart for Magma Electric Company's $10 \mathrm{MW}(\mathrm{e})$ geothermal binary plant at East Mesa, CA. In this binary design, geofluid at about $350^{\circ} \mathrm{F}$ is pumped from the wells to the plant using downole centrifugal punps. The heat from the geofluid is transferred to isobutane which is heated, vaporized, and superheated in she11-and-tube heat exchangers. The superheated isobutane passes through a knockout drum and is supplied at $350^{\circ} \mathrm{F}$ and 500 psia through a " $y$ " connection to the two tandem-mounted turbines.

After the expanded isobutane leaves the turbines, residual heat is transferred to a propane loop which powers a turbogenerator designed to provide the parasitic load for operating the plant. The isobutane is then condensed to 1 iquid in she11-and-tube condensers which are cooled with treated water from a large spray pond system. The cooled isobutane is repressurized by a boiler feed pump and returned to the heat exchangers for reheating.

The heat exchangers are indicated as six heaters, two boilers, and two superheaters in the flowchart of Figure 2-2. Fach heat exchanger contained 109 carbon steel tubes that were 77 feet long and originally had 0.035 inch (nomina1) walls. The $13 / 16$ inch diameter tubes were bundled and supported in the exchangers by a unique design which incorporated deformed short tubes shaped to fit within each cluster of seven tubes as spacers. These spacers were held in place by the clamping action of a strap around each cluster. The exchanger tube bundle was made up by interlacing the tube clusters along their length as well as laterally across the tube bank [Dambly 1978].

In al1 heat exchangers, the isobutane was on the tube side, and the geothermal fluid was on the shell side. The geothermal fluid entered heat exchanger 10 at $350^{\circ} \mathrm{F}$ and exited heat exchanger 1 at $167^{\circ}$ to $176^{\circ} \mathrm{F}$. 


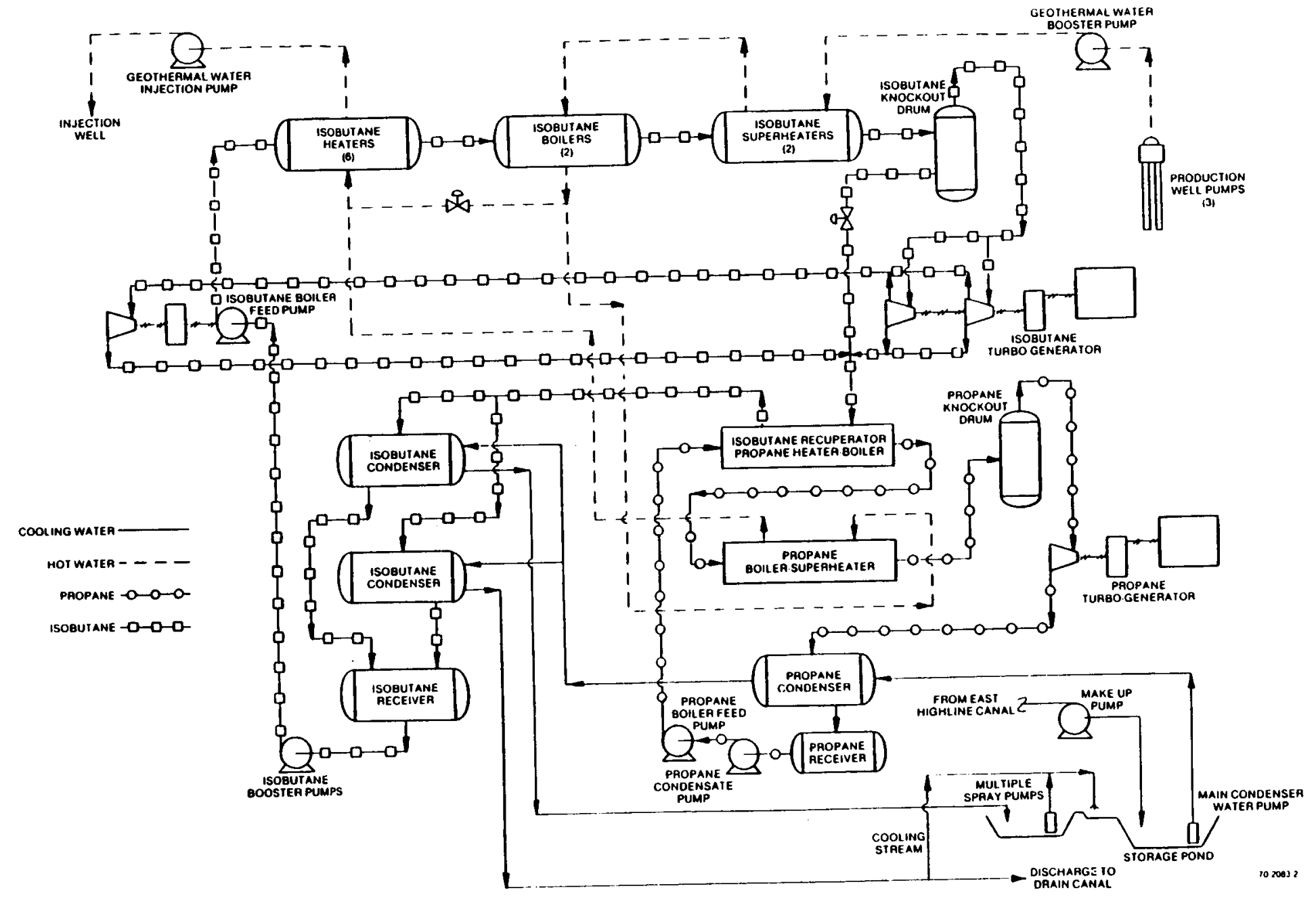

Figure 2-2. Flow Chart of the Magma 10MW Geothermal Binary Plant [E11is and An1iker 1982] 
The plant started operation in November 1979, and shut down in November 1981 for retubing of the heat exchangers. During this period, the plant was operated about 50 percent of the time. During periods of shutdown, the heat exchangers were drained, but geothermal fluid was not completely removed from the bottom of the shells. Additionally, the exchangers were left open to the air for days at a time. Tubes from the bottom regions of three exchangers were immersed in geothermal fluid during shutdowns, while the upper regions were exposed to refluxing geothermal vapors [An1iker and E11is 1982].

\subsection{Heber}

Two separate heat exchanger performance tests have been executed at Heber, using essentially the same equipment in each test. The first test was actually a series of short-term tests in 1974 and 1975, henceforth identified as the "Heber 560hr tests" [Lombard 1975]. The second test was a longer term (actually 2023hr) test beginning 1 ate in 1976, designated as the "Heber $2000 \mathrm{hr}$ test" [Holt 1978].

Both of these tests used the same Heat Exchanger Test Unit (HETU), designed and constructed by the Ben Holt Company. The HETU consisted of four twenty-foot 1 ong heat exchangers in series. Each heat exchanger contained four tubes 0.75 inch in diameter with 16 BWG tube walls (nominal thickness 0.065 inch). Geof 1 uid flowed tubeside.

Heat was extracted from the geofluid by distilled water treated with corrosion inhibitors circulating in a closed loop. Heat was rejected from the distilled water loop via another heat exchanger serviced with evaporatively cooled irrigation water.

During the $560 \mathrm{hr}$ tests, each of the four heat exchangers were tubed with the same metal. Three different alloys--carbon stee1, 90/10 cupronickel (CA 706), and titanium-were tested at geofluid velocities of 5, 10, and 15 ft/sec. Geofluid for these tests was provided by a downell pump in Nowlin No. 1 we11. Pressure was maintained at 195 psig to prevent any $f 1$ ashing or breakout of dissolved carbon dioxide. 
During the $2000 h r$ tests, heat exchangers E-1 and E-3 were equipped with ASTM A-179 carbon steel tubes, while exchangers E-2 and E-4 were tubed with ASTM B-338 titanium. During this test, geofluid was produced from Nowlin No. 1 by natural flow. Flow volumes were reduced so that the production pressure would remain above the carbon dioxide breakout pressure, keeping all carbon dioxide in solution. This limited the geofluid velocity to 5 fps. Carbon dioxide was not vented from the system during the test. To the best knowledge of the $2000 \mathrm{hr}$ test operator, carbon dioxide evolution did not occur [Ho1t 1982].

During the $560 \mathrm{hr}$ tests, the geofluid TDS was $14,500 \mathrm{ppm}$. No other data were reported. Table 2-4 presents a summary of corrosion and scaling chemistry data from an analysis made on $19 \mathrm{January} 1977$ during the $2000 \mathrm{hr}$ test.

\subsection{Salton Sea}

This test was conducted 17-21 June 1973 using geofluid from Magmamax No. 1 well in the Salton Sea resource. The purpose of the test was to determine heat transfer degradation in heat exchangers serviced with hot Salton Sea geofluid as proposed in the initial plans for the Geothermal Loop Experimental Facility (GLEF) [Fe1singer 1973].

The heat exchanger used in this test consisted of a ten-foot 1ong, 4inch diameter steel shell equipped with flanges for connection to the geofluid 1 ine. The two tubes were $9.5 \mathrm{ft}$ long, 1 inch od titanium secured in the tubesheets by swagelok fittings with Tefion ferrules. Heat was exchanged to distilled water in a closed 100 .

Prior to entering the heat exchanger, the geofluid was flashed to a pressure and temperature of $150 \mathrm{psig}$ and $375^{\circ} \mathrm{F}$, and the steam fraction was separated. Table 2-5 is a representative analysis of flashed Magmamax No. 1 geofluid, though the conditions under which the samples were collected are not necessarily those operative during the heat exchanger test. 
TABLE 2-4. CHEMISTRY OF NOWLIN NO. 1 GEOFLUID AS MEASURED DURING THE HEBER 2000HR TEST

\begin{tabular}{lcc}
\multicolumn{1}{c}{ Component } & Concentration (ppm except pH) \\
\hline pH (field) & $5.5-5.6$ \\
Chloride & 7700 \\
Sulfate & 75 \\
Bicarbonate & 40 \\
Carbon Dioxide (Total) & 180 \\
Hydrogen Sulfide & $<2$ \\
Ammonia & 9.2 \\
Silica & 253 \\
Calcium & 840 \\
Magnesinm & 0.6 \\
TDS & 13,900 \\
\hline \hline
\end{tabular}

Source: Shannon 1978 
TABLE 2-5. REPRESENTATIVE CHEMISTRY OF FLASBED GEOFLUID FROM MAGMAMAX NO. 1

\begin{tabular}{lc} 
Component & Concentration (ppm except pH) \\
\hline pH & 120,374 \\
Chloride & 10 \\
Sulfate & -1 \\
Bicarbonate & 4472 \\
Carbon Dioxide (Total) & 16 \\
Hydrogen Sulfide & 558 \\
Ammonia & 426 \\
Silica & 23,090 \\
Calcium & 108 \\
Magnesium & 203,406 \\
TDS &
\end{tabular}

Source: Elits and Conover 1981 
In order to evaluate the pattern of deposition in geothermal heat exchangers in Iceland, some field trials were carried out using simulated heat exchanger tubes. These studies are of potential interest since conditions may reflect cold end conditions in some geothermal power plants. Fouling studies were caried out at Svartsengi and Hveragerdi, both situated in the southwest of Iceland. At Hveragerdi the geothermal fluid is of rain water origin but at Svartsengi the fluid originates from sea water [Bott and Gudmundsson 1978; 1979; Gudmundsson 1979].

The heat exchanger used consisted of a 78.75 inch 1 ength of 0.50 inch OD Type 316 stainless steel tubing. 59.0 inches of this length were enclosed in a stainless steel water jacket and the entire unit was insulated. The assembly was oriented vertically during the tests. Geofluid flow was tubeside, with countercurrent cooling water flow in the $j$ acket.

The geofluid used in the Svartsengi tests was derived from a well with a base temperature of $414^{\circ} \mathrm{F}$. The two-phase flow was separated at atmospheric pressure in a cyclonic separator. A small portion of the separated 1 iquid at $195^{\circ} \mathrm{F}$ was supplied to the test heat exchanger. The heat exchanger was located close to the wellhead so that the separated water, supersaturated with silica, passed through the heat exchanger seconds after separation.

At Hveragerdi, the geothermal water was taken from the district heating mains. The mains are provided with geothermal water separated at atmospheric pressure from two-phase flow produced from two we11s about $0.3 \mathrm{mi}$ from town. The resource temperature is about $392{ }^{\circ} \mathrm{F}$. The separated geothermal water at $177^{\circ} \mathrm{F}$ arrived at the experimental heat exchangers about 20-30 minutes after separation. Table 2-6 provides data on the chemistries of the geothermal water supplied to the test heat exchangers at each site. 
TABLE 2-6. COMPOS TTIONS OF GEOTHERMAL WATERS USED IN THE ICELANDIC HEAT EXCHANGER TRIALS

\begin{tabular}{|c|c|c|}
\hline \multirow[b]{2}{*}{ Component } & \multicolumn{2}{|c|}{ Concentration (ppm except $\mathrm{pH})$} \\
\hline & Svartsengi & Hveragerdi \\
\hline pH & 7.5 & 9.46 \\
\hline Chloride & 16,125 & 126 \\
\hline Sulfate & 37.6 & 54.9 \\
\hline Bicarbonate & $-\infty$ & -- \\
\hline Carbon Dioxide (Tota1) & 19.3 & 119 \\
\hline Hydrogen Sulfide & 0.1 & 4.7 \\
\hline Ammoni a & -- & -- \\
\hline Silica & 581 & 305 \\
\hline Calcium & 1227 & 3.2 \\
\hline Magnesium & 5.9 & 0.3 \\
\hline TDS & 29,642 & - \\
\hline
\end{tabular}

- data not available

Source: Gudmundsson 1979 
This section considers the results of fouling tests at a number of geothermal locations. A brief description of each of these tests was presented in Section 2. This section is divided into two principal parts. Section 2.1 presents a summary of fouling factor data from all of the fouling factor tests, while Section 2.2 presents more detail for each test.

\subsection{Overview of Foyling Factor Data}

The fouling factor is defined by:

$$
R_{f}=\frac{1}{U_{f}}-\frac{1}{U_{c}}
$$

$$
\text { where: } \begin{aligned}
R_{f}= & \text { fouling factor in }(h r)\left(f^{2}\right)\left({ }^{\circ} \mathrm{F}\right) / B t u \\
U_{f}= & \text { heat transfer coefficient of fouled heat exchanger in } \\
& B t a /(h r)\left(f t^{2}\right)\left({ }^{\circ} F\right) \\
U_{c}= & \text { heat transfer coefficient of clean heat exchanger }
\end{aligned}
$$

In the report of the Heber $560 \mathrm{hr}$ Tests [Lombard 1975] it was shown that the plots of the logarithm of the fouling factor were linear with respect to the logarithm of elapsed time $(t)$ or

$$
\ln R_{f}=\ln b+n \ln t
$$

and that the correlation coefficient was extremely high (>0.99) (the square of the correlation coefficient represents the fraction of scatter in $R_{f}$ which is accounted for by scatter in $t$ ), and a correlation coefficient of \pm 1.0 represents perfect correlation. This close correlation, indicating ittle unaccounted for scatter in the data, was demonstrated whether or not the decay in heat transfer coefficient itself was linear with time. 
The above equation is of course the logarithmic form of the power curve equation, which expressed in terms of $R_{f}$ and $t$, has the form

$$
\mathbf{R}_{\mathbf{f}}=\mathbf{b} \mathbf{t}^{\mathbf{n}}
$$

The Heber 2000hr study [Ho1t 1978] produced algorithms for predicting the heat transfer coefficient with passage of time, as discussed in Section 2.2. These algorithms were used to generate 14 synthetic heat transfer coofficients at 25 day intervals. These synthetic data were then fitted to equation 3.2 with a correlation coefficient of 20.96 . The report of this study did not present an expression for the composite heat transfer coefficient of the four separate stages. A composite was created from a weighted average of the predicted heat transfer coefficients of the individual stages. These coefficients were weighted in proportion to the contribution of each stage to the total heat transfer when clean (unfouled). Twenty synthetic points 25 days apart were computed and fitted to equation 3.2 with a correlation coefficient of 0.98 .

In the case of the Salton Sea fouling data, pub1ished experimental values [Felsinger 1973] of the heat transfer coefficient with increased test duration were converted to $R_{f}$ values and fitted to equation 3.2 , again with a correlation coefficient of $\geq 0.98$.

Thus, it appears that the power curve expression of equation 3.3 is a good descriptor of the time dependence of the fouling factor in each of the 14 cases in which this analytical approach was tried.

Table 3-1 presents a summary of the results of this fouling factor analysis for the available field trial data. This table indicates the trial heat exchanger inlet and outlet temperatures, fluid velocity, and test duration. Also presented are the power curve relationships between fouling factor and elapsed time, as well as the projected time required to reach a fouling factor of $0.002(\mathrm{hr})\left(\mathrm{ft} \mathrm{t}^{2}\right)\left({ }^{\circ} \mathrm{F}\right) / \mathrm{Btu}$, a common design value recommended by the 
TABLE 3-1. ONERVIEW OF POWERPLANT GEOFLUID HEAT EXCHANGER FODLING EXPERIENCE

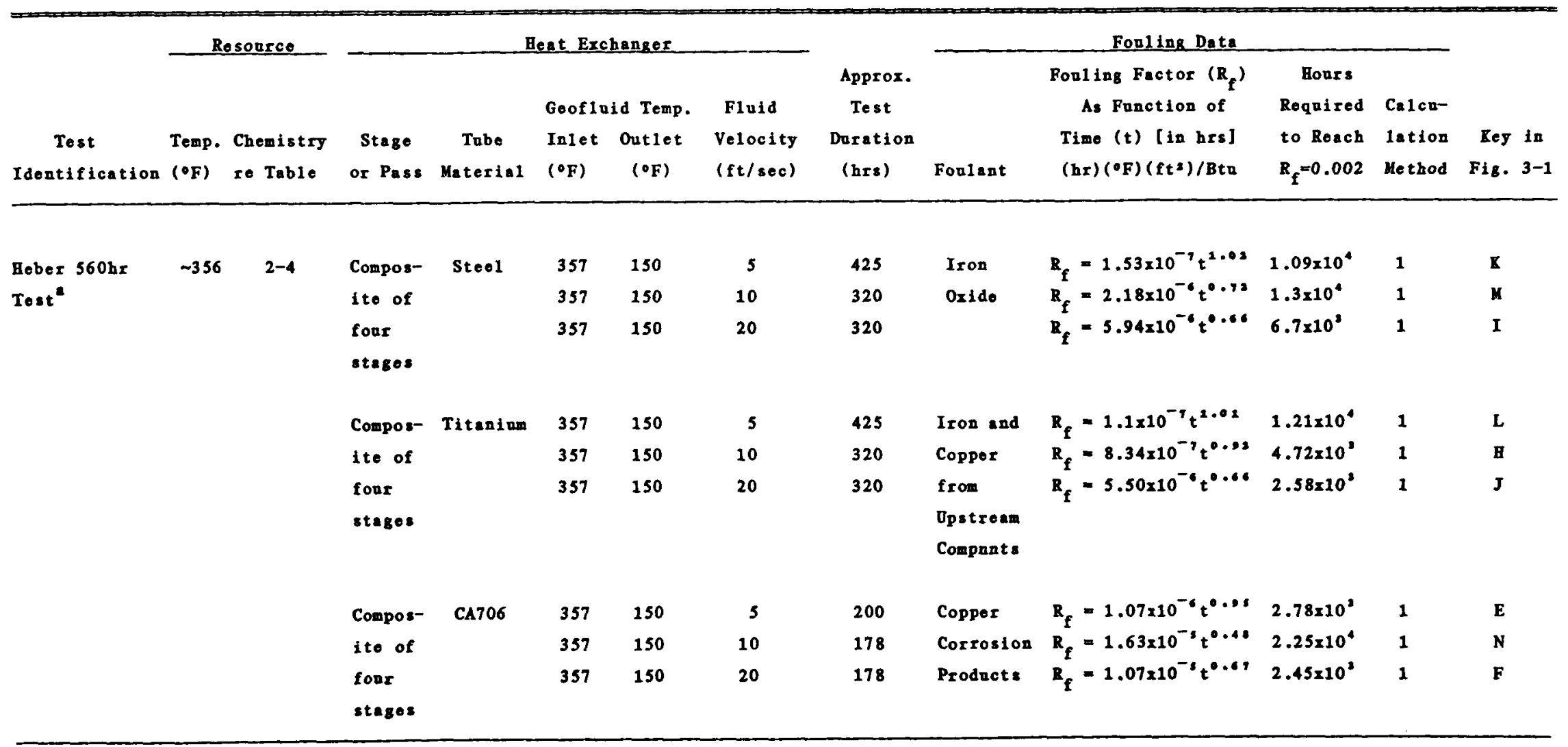

(Contined) 
TABLE 3-1. ONERVIEW OF POWERPLANT GEOFLUID HEAT EXCHANGER FOULING EXPERIENCE (Continued)

\begin{tabular}{|c|c|c|c|c|c|c|c|c|c|c|c|c|c|}
\hline \multirow[b]{2}{*}{$\begin{array}{c}\text { Test } \\
\text { Identification }\end{array}$} & \multirow[b]{2}{*}{$\begin{array}{l}\text { Temp. } \\
\left({ }^{\circ} \mathrm{F}\right)\end{array}$} & \multirow[b]{2}{*}{$\begin{array}{l}\text { Chemistry } \\
\text { ro Table }\end{array}$} & \multirow[b]{2}{*}{$\begin{array}{c}\text { Stage } \\
\text { or Pass }\end{array}$} & \multirow[b]{2}{*}{$\begin{array}{c}\text { Tube } \\
\text { Material }\end{array}$} & \multicolumn{3}{|c|}{ eat Exchanger } & \multirow[b]{2}{*}{$\begin{array}{l}\text { Approx. } \\
\text { Test } \\
\text { Daration } \\
\text { (hrs) }\end{array}$} & \multirow[b]{2}{*}{ Fonjant } & \multicolumn{2}{|l|}{ Fonling Date } & \multirow[b]{2}{*}{$\begin{array}{l}\text { Calca- } \\
\text { lation } \\
\text { Method }\end{array}$} & \multirow[b]{2}{*}{$\begin{array}{l}\text { Tey in } \\
\text { Fig. 3-1 }\end{array}$} \\
\hline & & & & & $\begin{array}{l}\text { Goof } 1 \mathrm{n} \\
\text { In1et } \\
\text { (oF) }\end{array}$ & $\begin{array}{l}\text { Id Temp. } \\
\text { Outlet } \\
\text { (OF) }\end{array}$ & $\begin{array}{l}\text { Fluid } \\
\text { Velooity } \\
(\mathrm{ft} / \mathrm{sec})\end{array}$ & & & $\begin{array}{l}\text { Foul ing Factor }\left(\mathbb{R}_{f}\right) \\
\text { As Function of } \\
\text { Time }(t)[\text { in hrs] } \\
(\mathrm{hr})\left({ }^{\circ} \mathrm{F}\right)\left(\mathrm{ft} \mathrm{t}^{2}\right) / \mathrm{Btz}\end{array}$ & $\begin{array}{c}\text { Hours } \\
\text { Required } \\
\text { to Reech } \\
R_{f}=0.002\end{array}$ & & \\
\hline \multirow[t]{5}{*}{$\begin{array}{l}\text { Heber } 2000 \mathrm{hr} \\
\text { Test }\end{array}$} & $\sim 356$ & $2-4$ & First & Steel & 350 & 235 & 5 & 2034 & $\begin{array}{l}\text { Corrosion } \\
\text { Products } \\
\text { and } \\
\text { Minerals }\end{array}$ & $R_{f}=1.48 \times 10^{-4} t^{0.16}$ & $1.17 \times 10^{7}$ & 2 & $\mathbf{R}$ \\
\hline & & & Socond & Titanium & 235 & 180 & 5 & 2034 & $\begin{array}{l}\text { Antimony } \\
\text { Sulfide }\end{array}$ & $R_{f}=1.58 \times 10^{-6} t^{0.36}$ & $3.47 \times 10^{8}$ & 2 & $\mathbf{s}$ \\
\hline & & & Third & Steel & 180 & 145 & 5 & 2034 & $\begin{array}{l}\text { Corrosion } \\
\text { Products } \\
\text { and } \\
\text { Minerals }\end{array}$ & $R_{f}=5.97 \times 10^{-3} t^{0.46}$ & $4.18 \times 10^{4}$ & 2 & 0 \\
\hline & & & Fourth & Titanium & 145 & 130 & 5 & 2034 & $\begin{array}{l}\text { Antimony } \\
\text { Sulfide }\end{array}$ & $R_{f}=1.12 \times 10^{-8} t^{0.20}$ & $7.86 \times 10^{4}$ & 2 & $\mathbf{p}$ \\
\hline & & & $\begin{array}{l}\text { Compos- } \\
\text { ite }\end{array}$ & & 350 & 130 & 5 & 2034 & & $R_{f}=4.58 \times 10^{-1} t^{0.30}$ & $2.93 \times 10^{8}$ & 2 & $a$ \\
\hline
\end{tabular}


TABLE 3-1. ONERVIEW OF POWERPLANT GEOFLUID EXCHANGER FODLING EXPERIENCE (Continued)

\begin{tabular}{|c|c|c|c|c|c|c|c|c|c|c|c|c|c|}
\hline \multirow[b]{2}{*}{$\begin{array}{l}\text { Test } \\
\text { Identification }\end{array}$} & \multirow[b]{2}{*}{$\begin{array}{l}\text { Temp. } \\
\left({ }^{\circ} \mathbf{F}\right)\end{array}$} & esource & \multicolumn{5}{|c|}{ Heat Exchanger } & \multirow[b]{2}{*}{$\begin{array}{l}\text { Approx. } \\
\text { Test } \\
\text { Duration } \\
\text { (hrs) }\end{array}$} & \multicolumn{4}{|c|}{ Fon1ing Date } & \multirow[b]{2}{*}{ Fey in } \\
\hline & & $\begin{array}{l}\text { Chemistry } \\
\text { ro Table }\end{array}$ & $\begin{array}{l}\text { Stage } \\
\text { or Pass }\end{array}$ & $\begin{array}{l}\text { Tube } \\
\text { Material }\end{array}$ & $\begin{array}{l}\text { Gooflus } \\
\text { Inlet } \\
\left({ }^{\circ} \mathrm{F}\right)\end{array}$ & $\begin{array}{l}\text { id Temp. } \\
\text { Outlet } \\
\left({ }^{\circ} \mathrm{F}\right)\end{array}$ & $\begin{array}{l}\text { Fluid } \\
\text { Velocity } \\
\text { (ft/sec) }\end{array}$ & & Fonlent & $\begin{array}{c}\text { Fouling Factor }\left(R_{f}\right) \\
\text { As Function of } \\
\text { Time }(t)[\text { in hrs] } \\
(h r)(\circ F)\left(f t^{2}\right) / B t u\end{array}$ & $\begin{array}{c}\text { Hours } \\
\text { Required } \\
\text { to Reach } \\
R_{f}=0.002\end{array}$ & $\begin{array}{l}\text { Calco- } \\
\text { lation } \\
\text { Method }\end{array}$ & \\
\hline $\begin{array}{l}\text { East Mesa } \\
\text { Testc }\end{array}$ & 350 & $2-1$ & $\begin{array}{l}\text { Six } \\
\text { stages }\end{array}$ & Steel & 340 & 150 & $\sim 4$ & 1172 & $\begin{array}{l}\text { None } \\
\text { Reported }\end{array}$ & \multicolumn{4}{|c|}{$\begin{array}{l}\text { No statistically slgnificant change in heat } \\
\text { transfex coefficient detected during the Tost }\end{array}$} \\
\hline $\begin{array}{l}\text { Salton Soa } \\
\text { Test }\end{array}$ & & $2-5$ & Singlo & Titanium & 375 & 342 & 5 & 1400 & Silica & $R=2.54 \times 10^{-7} t^{2.08}$ & $7.5 \times 10^{1}$ & 3 & $A$ \\
\hline Svartsengi & 415 & $2-6$ & $\operatorname{sing} 1 e$ & Type 316 & 195 & 163 & 4.6 & 791 & Silica & $R_{f}=7.09 \times 10^{-7} t$ & $2.82 \times 10^{3}$ & 4 & D \\
\hline (Iceland) Tost ${ }^{\circ}$ & & & Single & Type 316 & 196 & 156 & 4.0 & 766 & Silica & $R_{f}=4.26 \times 10^{-7} t$ & $4.69 \times 10^{3}$ & 4 & G \\
\hline $\begin{array}{l}\text { Hveragerdi } \\
\text { (Icoland) Tost }\end{array}$ & 392 & $2-6$ & $\begin{array}{l}\text { Single } \\
\text { Single }\end{array}$ & $\begin{array}{l}\text { Type } 316 \\
\text { Type } 316\end{array}$ & $\begin{array}{l}177 \\
176\end{array}$ & $\begin{array}{l}154 \\
144\end{array}$ & $\begin{array}{l}4.5 \\
2.3\end{array}$ & $\begin{array}{l}2035 \\
2035\end{array}$ & $\begin{array}{l}\text { Silica } \\
\text { Silica }\end{array}$ & $\begin{array}{l}R_{f}=1.82 \times 10^{-6}(t-650) \\
R=2.27 \times 10^{-6}(t-650)\end{array}$ & $\begin{array}{l}1.75 \times 10^{3} \\
1.53 \times 10^{3}\end{array}$ & $\begin{array}{l}4 \\
4\end{array}$ & $\begin{array}{l}\text { C } \\
\text { B }\end{array}$ \\
\hline
\end{tabular}

Calculation Methods:

1. Curve fitting of published values of Fouling Factor after different service periods

2. Curve fitting of $R_{f}$ values based on published algorithms for prediction of heat transfor coefficient with time

3. Curve fitting of $R_{f}$ values calculated from published fouled heat transfer coefficients

4. Pablished relationship of $R_{f}$ as a function of service period

Rombard 1975

bHo1t 1978

${ }^{c}$ Silvester and Doyle 1982

dFelsinger 1973

BBott and Gudmundsson 1978; 1979; Gudmends son 1979 
Tubular Heat Exchanger Manufacturers' Association (TEMA) [Fischer et al 1975]. However, some caution should be used in extrapolating the results of short tests to predict fouling factors after exposures more than an order of magnitude longer than the actual test period.

Figure 3-1 presents the same time dependence of fouling factor data in graphical form, and the same caviat applies regarding extrapolation.

At Heber and East Mesa, the primary expected mineral deposition is calcium carbonate. However, simply lowering the temperature cannot precipitate this compound. An increase in $\mathrm{pH}$, resulting from evolution of carbon dioxide from solution, is required. In the tests at these resources (which are presented in Table 3-1), the geofluid supply was operated at sufficient pressure to prevent carbon dioxide evolution. The three tests showed no significant deposition of calcium carbonate, demonstrating that preventing "f1ashing" of the geofluid will indeed prevent calcium carbonate fouling of binary power plant heat exchangers at these resources.

Al so worthy of note in these results are the difference in fouling between carbon steel and cupronickel tubes which corrode, and titanium tubes which are highly corrosion resistant. The data show that carbon steel and cupronickel can be expected to foul much more rapidly than an inert alloy. A significant portion of the deposits on carbon steel were found to be corrosion products.

The 1 imited available data indicate that in the cases where calcium carbonate is the major potential foulant, maintenance of pressure to keep the carbon dioxide in solution will probably allow operation with only annual cleaning. Scaling is likely to be a more severe problem at resources where silica is the major foulant. Deposition rates appear greater and the scale is more difficult to remove. 


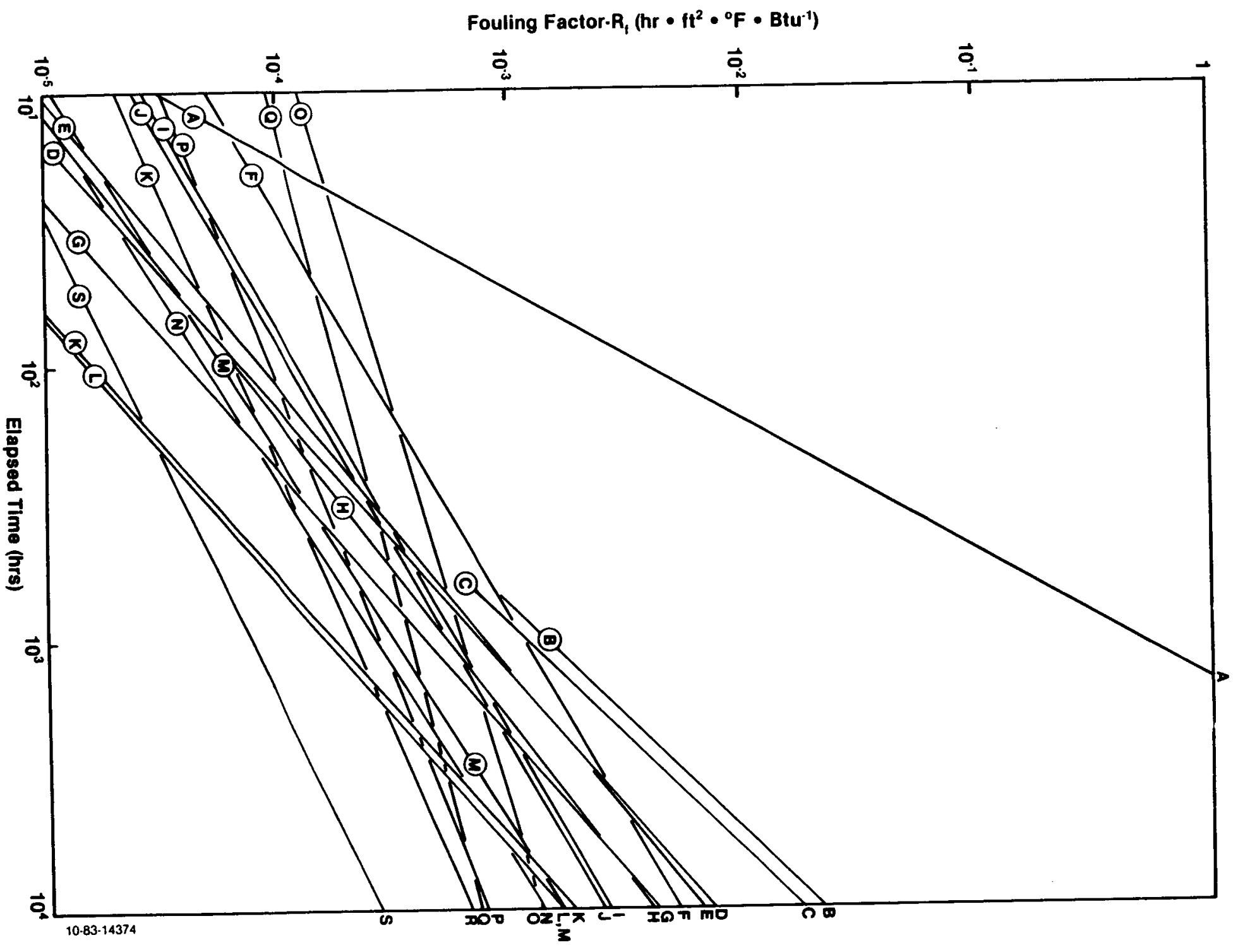

Figure 3-1. Time Dependence of Fouling Factor for a Number of Geothermal Heat Exchangers (Tab1e 3-1 presents the test conditions and the equations used to generate this figure). 


\section{Heber $560 \mathrm{hr}$ Tests}

These tests showed an essentially 1 inear decrease in $U_{f}$ with time for stee1, titanium, and CA 706 (90/10 cupronicke1) when the geofluid velocity was 5 fps. The overall heat transfer for the four stages of heat exchanger were fitted to the following equation [Lombard 1975]:

$$
\begin{aligned}
& \mathbf{U}_{\mathbf{t}}=\mathrm{U}_{\mathrm{c}}-\mathbf{m} \mathbf{t} \\
& \text { where: } U_{t}=\text { the heat transfer equation at time } t \\
& U_{c}=\text { as previously defined } \\
& t=\text { elapsed time in hours } \\
& m \text { = rate of change of heat transfer coefficient }
\end{aligned}
$$$$
\text { eq } 3.4
$$

with the following values for steel, titanium, and cupronickel:

\section{Meta 1}

Carbon Stee1

Titani um

CA 706
Btu $/(h r)\left(f t^{2}\right)\left(S_{-O}^{\circ}\right)$

591

529

615

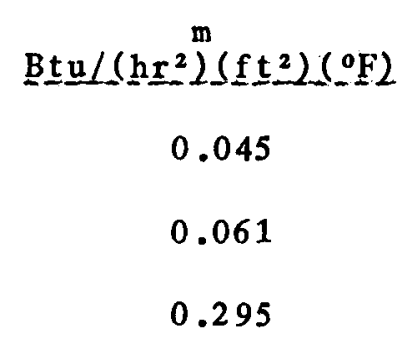

$B \underline{t} \underline{u} /\left(\underline{h r^{2}}\right)^{m}\left(f t^{2}\right)(o F)$

0.045

0.295

The decrease of the heat transfer coefficient with time was non1 inear at 10 and 20 fps for all three metals with the rate of decrease slowing and apparently becoming 1 inear after an initial pericd of more rapid fouling. Lombard [1975] found that for elapsed times greater than the time required for linear degradation of heat transfer to begin (t 1 inear), the fouled heat transfer coefficient could be predicted by:

$$
u_{t}=U_{t_{1 \text { inear }}}-m\left(t-t_{1 \text { inear }}\right)
$$

with the following values for $m, U_{t_{1}}$, and $t_{1 i n e a r}$ for geofluid velocities of 10 and $20 \mathrm{fps}$ : 


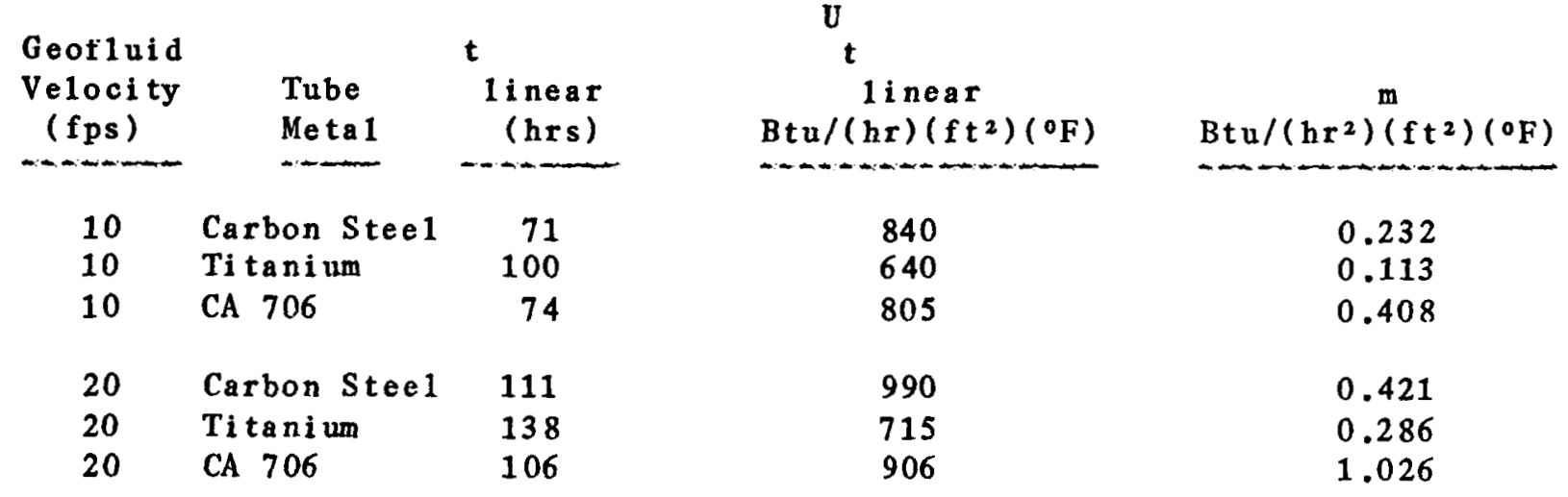

After 324 hrs of operation at 10 fps and with inlet and outlet temperatures of $353^{\circ} \mathrm{F}$ and $250^{\circ} \mathrm{F}$, the titanium tubes showed a film $0.6-0.7 \mathrm{mils}$ thick ( $1 \mathrm{mil}=0.001$ inch). Fnergy dispersive $X$-ray spectroscopy showed that the film on the titanium contained about 8 wt percent iron, as well as traces of sulfur, silicon, calcium, copper, magnesium and aluminum.

After similar exposure, the carbon steel tubes were found to have deposits $0.9 \mathrm{mils}$ thick. These deposits were found to be predominantly iron oxide, derived from corrosion of the carbon steel substrate.

The CA 706 tubes fouled nuch more rapidly, with a scale thickness 3-4 mils after only $200 \mathrm{hrs}$ of operation at the above conditions. This scale was reported to be mostly copper oxide corrosion products.

\subsubsection{Heber $2000 \mathrm{hr}$ Test}

As discussed previcusly, the four heat exchangers in this test were designated E-1 through E-4. These units had unfouled heat transfer coefficients $\left(U_{c}\right)$ of $890,639,741$, and $553 \mathrm{Btu} /(\mathrm{hr})\left(\mathrm{ft}^{2}\right)\left({ }^{\circ} \mathrm{F}\right)$, respectively. These coefficients were used with experimental data to calculate equations which best describe the change in heat transfer coefficient as a function of time. A number of different curves were fitted [Holt 1978]. The best fit was given by curves of the form: 
with the specifle results 1 isted below:

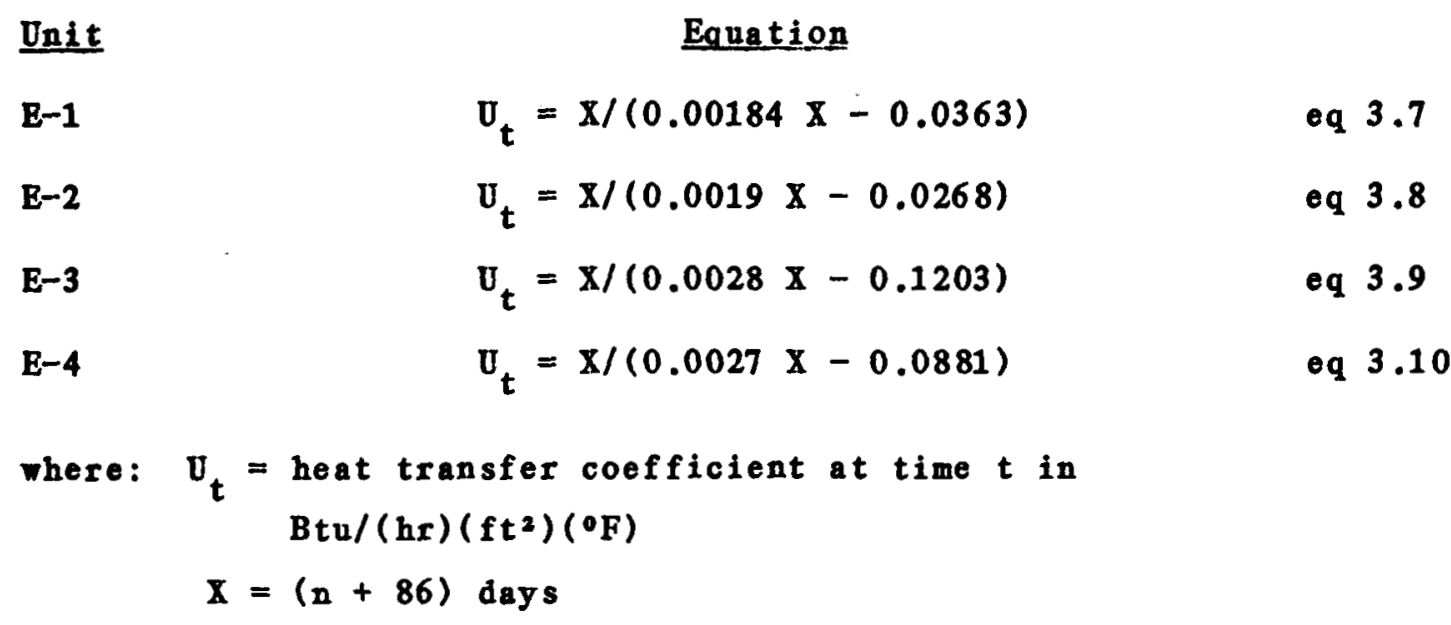

Holt [1978] used these equations to calculate the values of $R_{f}$ after 365 days. Holt al so projected the fouling factors for each heat exchanger stage in the previous Heber test (Section 3.2.1), assuming that fouling was 1inear with respect to time. The results are presented below:

Heat

Exchanger

E-1

$\mathbf{E}-\mathbf{2}$

E-3

E-4
Geofluid Temp.

Range (OF).

$350-235$

235-180

180-145

145-130
365 Day Fouling Factor (hr) $\left(\mathrm{ft}^{2}\right)\left({ }^{\circ} \mathrm{F}\right) / \mathrm{Btu}$ eq $3.7-10$ 560hr test
0.000576
0.0001
0.000280
0.0011
0.001182
0.0011
0.000679
0.0033

Note that carbon steel tubes were used in each heat exchanger in the $560 \mathrm{hr}$ test, while the tubes of $\mathrm{E}-2$ and $\mathrm{E}-4$ were titanium in the $2000 \mathrm{hr}$ test. The steel tubes show good agreement in calculated fouling factors [Holt 1978]. 
Table 3-2 presents a summary of energy dispersive spectroscopy analytical results from the scale deposits in the various tubes. These analyses indicate that the deposits on the titanium tubos were primarily antimony sulfide, though there also were likely to be a significant amount of oxides or carbonates of some metal. Conspicuous by its absence is calcium, demonstrating that maintaining adequate pressure can mitigate calcium carbonate scaling.

In the steel tubes, the primary detected element was iron, and it is deduced that the principal deposit was iron oxide and/or iron carbonate corrosion products. Some silica precipitation was also evident, but again calcium is conspicuous by its reported absence [Holt 1978].

\subsubsection{Sa1ton Sea Test}

This test showed that a geofluid heat exchanger at the Salton Sea resource would lose 60 percent of its heat transfer capacity and fall below a "design" fouling factor of $0.0035(\mathrm{hr})\left(\mathrm{ft}^{2}\right)\left({ }^{\circ} \mathrm{F}\right) / \mathrm{Btu}$ in 1 ess than $92 \mathrm{hrs}$ of steady-state operation. The degradation in heat transfer was linear throughout the test. Linear regression of the published data [Felsinger 1973], shows the following relationship:

$$
v_{t}=445-2.8 t
$$

where $U_{t}$ and $t$ have been previously defined.

The scale formed was predominantly silica. Hourly thermal shocking did not serve to retard scale deposition.

\subsubsection{Tests at Svartsengi and Hveragerdi}

The published reports of these tests [Bott and Gudmundsson 1978; 1979; Gudmundsson 1979] do not provide data on the rate of degradation of heat transfer coefficient with time. Rather, the time dependence of the fouling 
TABLE 3-2. ANALYSIS OF SCALE SCRAPED FROM TUBE WALL

\begin{tabular}{|c|c|c|c|c|c|c|c|c|c|c|c|}
\hline \multirow{2}{*}{$\begin{array}{c}\text { Heat } \\
\text { Exchanger }\end{array}$} & \multirow{2}{*}{$\begin{array}{l}\text { Scale } \\
\text { Thickness } \\
\text { (mils) }\end{array}$} & \multicolumn{9}{|c|}{ Constituent Blement (wt\%) } & \multirow[b]{2}{*}{ Other ${ }^{\mathrm{a}}$} \\
\hline & & $\mathbf{s}$ & $\mathbf{Z n}$ & Si & Fe & $\mathbf{C u}$ & $\mathbf{N i}$ & $\mathbf{C r}$ & As & $\mathbf{S b}$ & \\
\hline \multicolumn{12}{|c|}{ Steel Tubes } \\
\hline $\begin{array}{l}\text { E-1 } \\
\text { In1et } \\
\text { Out1et }\end{array}$ & $\begin{array}{l}2.0 \\
3.7\end{array}$ & $\begin{array}{l}5.8 \\
8.6\end{array}$ & $\underline{-1}^{\mathrm{b}}$ & $\begin{array}{l}13.2 \\
14.0\end{array}$ & $\begin{array}{l}34.9 \\
37.4\end{array}$ & $\begin{array}{l}1.1 \\
0.9\end{array}$ & $\begin{array}{l}0.5 \\
0.4\end{array}$ & $\begin{array}{l}0.4 \\
0.2\end{array}$ & 9.0 & 1.0 & $\begin{array}{l}30.3 \\
38.4\end{array}$ \\
\hline $\begin{array}{l}\text { E-3 } \\
\text { In1et } \\
\text { Outlet }\end{array}$ & $\begin{array}{l}1.9 \\
4.3\end{array}$ & $\begin{array}{l}4.9 \\
6.7\end{array}$ & $4.8^{b}$ & $\begin{array}{l}16.2 \\
10.5\end{array}$ & $\begin{array}{l}30.9 \\
24.4\end{array}$ & $\begin{array}{l}0.2 \\
3.0\end{array}$ & $\begin{array}{l}0.3 \\
1.2\end{array}$ & $\begin{array}{l}0.3 \\
2.8\end{array}$ & $\begin{array}{l}\text { nd } \\
0.5\end{array}$ & 2.0 & $\begin{array}{l}51.3 \\
50.0\end{array}$ \\
\hline \multicolumn{12}{|c|}{ Titanium Tubes } \\
\hline $\begin{array}{l}\mathrm{E}-2 \\
\text { In1et } \\
\text { Out1et }\end{array}$ & $\begin{array}{l}0.2 \\
0.5\end{array}$ & $\begin{array}{l}21.4 \\
20.2\end{array}$ & - & $\begin{array}{r}11.3 \\
3.4\end{array}$ & $\begin{array}{l}3.8 \\
0.8\end{array}$ & $\begin{array}{l}1.3 \\
1.0\end{array}$ & - & - & 3.9 & $\begin{array}{l}15.4 \\
48.2\end{array}$ & $\begin{array}{l}46.8 \\
22.5\end{array}$ \\
\hline $\begin{array}{l}\text { E-4 } \\
\quad \text { In1et } \\
\text { Out1et }\end{array}$ & $\begin{array}{l}0.5 \\
0.9\end{array}$ & $\begin{array}{l}19.0 \\
12.7\end{array}$ & $1.7^{b}$ & $\begin{array}{l}1.6 \\
0.4\end{array}$ & 0.8 & $\begin{array}{l}2.6 \\
0.5\end{array}$ & $\bar{m}$ & ${\underline{-0.2^{b}}}^{\mathrm{b}}$ & $\begin{array}{l}2.5 \\
2.5\end{array}$ & $\begin{array}{l}55.0 \\
41.2\end{array}$ & $\begin{array}{l}17.9 \\
42.8\end{array}$ \\
\hline
\end{tabular}

- Data not available or none detected

${ }^{2}$ Value obtained by difference, representing elements with atomic number less than nine (f1uorine), which are not detectable by the analytic technique ased.

$b_{\text {Not detected in all samples }}$

${ }^{c}$ Insufficient material obtained for bult analysis. The reported results are from in-situ surface analyses.

Source: Holt 1978 
factor itself was published, and is set forth in Table 3-1 for each of the four tests.

The results from Hveragerdi are interesting because the deposits formed a ripple pattern on the inside of the tube, and it was concluded that this pattern resulted from mass-transport phenomena.

Initially, this ripple pattern caused enhanced heat transfer, producing negative fouling factors. Fouling resistance reached a minimu at about $300 \mathrm{hrs}$ of operation. At $650 \mathrm{hrs}$ of operation the enhancement in heat transfer due to roughness became equal to the reduction due to deposition, and linear increase in the fouling factor began and continued throughout the rest of the test. At Svartsingi, there was no detected period of enhanced heat. transfer.

At Svartsengi and Hveragerdi, the principal foulant was silica scale. 



\subsection{CORROSION OF POWER PLANT GEOFLUID HEAT EXCHANGERS}

The amount of quantitative documented corrosion experience from actual or simulated geofluid/hydrocarbon heat exchangers is quite 1 imited largely because of two factors. First, few tests of such actual or simulated heat exchangers have been performed, and second, because most of the tests which have been done had measurement of fouling as their major or sole objective. This sma1l data base can be supplemented however, with the large amount of compiled corrosion test data taken under conditions which do not involve heat transfer [E11is and Conover 1981]. However, caution must be used in applying this data since corrosion is often intensified under heat transfer conditions, due to increased mass transport and thinning of the boundary 1ayer.

Despite the limited data, some conclusions can be reached. At the resources of near-term interest for binary power plant development--East Mesa, Heber, Raft River--uniform corrosion rates on the order of 3-7 mpy (mil/yr) can be expected for carbon steel. In addition, even under conditions which appear to rigorously exclude oxygen, carbon steel pitting rates of up to 46 mpy have been reported, though other tests show little or no pitting. Some or all of these geofluids can cause pitting of carbon steel even in the absence of oxygen.

Both uniform corrosion and pitting of carbon steel heat exchanger tubes are also greatly accelerated by even traces of oxygen introduced during shutdowns. The rigorous and complete exclusion of oxygen from heat exchangers at al1 times, whether or not the system is operating, appears to present tremendous practical problems for a large power plant.

It appears therefore that heat exchanger tube alloys capable of resisting both normal operating conditions and aerated geofluid are 1 ikely to be required. Currently the prime candidates appear to be Allegheny-Ludlum Alloys 29-4 and 29-4C (29Cr-4Mo ferritic stainless steels) and TiCode 12 (a titanium alloy). Other alloys such as SeaCure 26-3 and E-brite 26-1 have not 
been tested under conditions simulating geothermal binary evaporator service, but may also be shown to be of some usefulness after testing. Selection between the 29Cr-4Mo alloys and the titanium alloy is likely to be dictated by economic factors since their corrosion performance is likely to be comparable nnder most conditions.

\section{$4.1 \quad$ Heber}

At the end of $560 \mathrm{hr}$ tests, pits $3 \mathrm{mils}$ deep were measured in the carbon steel tubes [Lombard 1975]. Though it is risky to extrapolate pit depths into linear penetration rates (since pit penetration rate may not be linear), the annulized penetration rate was calculated to be about 45 mpy. The presence of iron oxide as the major deposit constituent indicates ongoing corrosion. However, the average measuxed wall thickness of 66 mils exceeds the nominal thickness of 16BWG, the tube specification. Therefore, a corrosion rate based on post-exposure wall thickness cannot be calculated.

The titanium tubes showed no evidence of corrosion, while CA706 (90/ 10 cupronickel) tubes showed significant (but unquantified) corrosion after $200 \mathrm{hrs}$. This corrosion was reported to be more severe than the carbon steel after 560 hrs [Lombard 1975].

An independent laboratory analysis of carbon steel tube samples from the $2000 \mathrm{hr}$ test concluded that there was evidence of pit growth, but that the propagation rate was probably not greater than 0.3 mpy [Holt 1978], which equates to a depth of only $0.07 \mathrm{mils}$ at the end of the test. This is extremely slight corrosion, and whether or not it constitutes pitting or uniform corrosion is debatable.

The $2000 \mathrm{hr}$ test appears to have been designed primarily to measure much-needed heat exchanger fouling factors. In addition, an estimate of the corrosion rate was made by determining the mass of iron in the scale at two points on the carbon steel heat exchanger tubing and attributing this iron to the corrosion of the steel tubing. Thus, the amount of iron corroded from the 
tubing was equated to the amount of iron in the scale. This method necessarily assumes that the scale measured for the estimate represents all of the scale formed at the locations selected for corrosion rate measurements [Holt $1978]$.

However, stereomicroscopic examination of the scale deposits later used in the corrosion rate estimates showed these scales to be porous; composed of plates with ridges; mechanically brittle; and easily broken or crumbled. The examination showed that pieces of the scale had "flaked" or "chunked" away and that new deposits were growing on the fracture surfaces.

The regrowth of new deposits on the fractures in the scale demonstrates that the "chunking" or "flaking" off occurred during the test, not after the tubes were removed, and clearly establishes that pieces of the scale were broken away from the deposit and carried away by the geofluid. Therefore, the mass of iron present in the scale cannot represent the total amount of iron corroded from the tube at that site, and the corrosion rate $(0.3 \mathrm{mpy})$ estimated by this method must be 10 by some unknown but potentially significant factor.

Several other data can be used to bracket the probable carbon steel corrosion rate at Heber. Concurrently with the 2000hr test, a 42-day (approximately 1000hr) coupon (weight-1oss) corrosion test was performed in the geofluid supply line a short distance upstream of the IETU [Syrett et al 1977; Underhil 1 1982]. ASTM-type coupons of steel were used and weight-1oss from the coupons without removal of the scale deposits was equivalent to a corrosion rate of approximately $2.7 \mathrm{mpy}$. This represents a minimum corrosion rate, as removal of the scale would have shown a more accurate-and greater-weight loss, and thus a higher corrosion rate.

Corrosion tests were also performed according to ASTM practices at East Mesa wel1 6-1 in 1977. The unflashed brine used in this test was comparable in terms of carbon steel corrosivity chemistry to the Heber case. The measured corrosion rate for carbon steel was around six mpy [Shannon 1977]. 
Long-term (109 day) corrosion tests were also performed at Raft River, whose carbon steel corrosivity chemistry is milder than that of Heber or East Mesa. Twelve carbon steel coupons showed corrosion rates of 1.2-3.4 mpy. Eleven of the 12 coupons also experienced pitting with an average penetration rate of 18 mpy and a maximum of 43 mpy. These tests were performed with the careful exclusion of oxygen, making oxygen attack an unlikely explanation for the serious pitting [Miller 1977].

Thus, it seems reasonable that a lower bound for the "uniform" corrosion of carbon steel at Heber is around three mpy, while tests at a quite similar resource suggest that a "uniform" corrosion rate of around six mpy is likely. This result is close to the eight mpy estimate derived by F1uor's independent consultant [Meiran 1982] for design of the SDG\&E 50MW binary p1ant.

If it occurs, pitting-rather than "uniform" corrosion--is the corrosion mode which determines the useful life of thin-walled components such as heat exchanger tubing. The issue of pitting resistance is unresolved. The carbon steel tubes in the $2000 \mathrm{hr}$ tests were reported to have pit penetration of about 0.3 mpy [Ho1t 1978], which equates to a depth of $\sim 0.07$ mils at the end of the test. However, the earlier $560 \mathrm{hr}$ pumped geofluid HETU test at Heber showed pits about three mils deep for an annualized rate of 46 mpy, and as stated previously, tests at Raft River showed comparable attack. Since the latter test carefully excluded air, it does not seem that all such pitting attack can be attributed to air inleakage during upsets. Some, or a11, of these geofluids can cause pitting of carbon steel in the absence of oxygen.

\subsection{East Mesa}

Magma Power Company's 10MW P1ant

As discussed in Section 2, the Magma Plant has ten heat exchangers in its hydrocarbon evaporation system. These exchangers, with carbon steol 
tubes, receive $350^{\circ} \mathrm{F}$ geofluid at the inlet of the first heat exchanger, and exhaust $167^{\circ} \mathrm{F}$ fluid at the end of the train.

Plant operation began in November 1979 and continued for about two years, at which time the tubes in the geofluid/hydrocarbon heat exchangers had failed by pitting. During the first two years of operation, the p1ant was operative about 50 percent of the time. During shutdown periods, the heat exchangers were drained, but geofluid was not completely removed from the bottoms of the shelis (the fluid was shellside contrary to common practice). Additionaly, the exchangers were left open to the air for days at a time. Tubes from the lower regions were immersed in geofluid during shutdowns, while those in upper regions were exposed to refluxing geothermal vapors and moisture [Anliker and E11is 1982].

After 15 months of operation, a number of ultrasonic measurements of tube wall thickness were made [Shannon et al 1981]. Twenty-eight of 29 reported tube wall thicknesses were statistically evaluated (by Radian) to determine the average remaining thickness (one point was excluded as it was the site of mechanical wear). The average remaining wall thickness was $26.8 \pm 1.2$ mils ( 95 percent confidence interval). The maximum and minimum values were 30 and $20 \mathrm{mils}$ respectively [Smith and E11is 1983].

Assuming that the actual original wall thickness was the nominal 35 mils, then the average thickness 1oss was 7.0-9.4 mils after 15 months, for an approximate corrosion rate of 5.6-7.5 mpy. These estimates probably represent an "averaging" of metal thickness in pits and unpitted areas, since most pits were probably smaller in area than the ultrasonic probe area. Four of the measurements indicated pits up to 20 mils deep.

After failure at the end of two years, some of the carbon steel tubes were subjected to failure analysis [Anliker and E11is 1982]. A11 tube sections analyzed were coated on interior and exterior surfaces with a tenacious dark deposit 3 to 6 mils thick. Covering this deposit was a redishbrown powdery deposit several mils thick. The reddish-brown deposits from the 
interior and exterior of several tubes were analyzed separately by energy dispersive $X$-ray spectroscopy for elemental identification and by $X$-ray diffraction for compound identification. They were all determined to be the same iron oxide/sulfide/carbonate scale.

The tubes had suffered from three corrosion mechanisms: "uniform" corrosion, crevice corrosion, and pitting. Wall thickness was estimated by averaging over 200 optical metallograph readings from unpitted areas. Uniform corrosion appeared to be about 2-5 mpy, assuming that the initial tube wall was 35 mils. Since some of the post-exposure wall thickness measurements exceeded 35 mils, the original wall was obviously greater than 35 mils. Therefore, the actual corrosion rate was greater than 2-5 mpy. Crevice corrosion to a depth of 4 mils appeared where spacers and bands contacted the tubes; it had not caused any perforations.

Pitting of tubes was determined to have caused the failure of the heat exchangers. There was about one perforated pit for each two 1 inear feet of exchanger tubing. Exposure to oxygen allowed to enter during downtimes and to carbon dioxide during normal operation were apparently the major causes of the pitting. Much of the damage likely occurred during shutdown periods.

\section{Simulated Heat Exchanger Tube Corrosion Test}

This test was designed to compare the performance of two alloys, Allegheny-Ludlum 29-4 and 29-4C under flow conditions simulating a geofinid/ hydrocarbon heat exchanger. The test conditions were discussed in some detail in Section 2 .

One section of specimens was exposed to $349.5^{\circ} \mathrm{F}$ geofluid for 1032.25 hours. There were two shutdown periods, one of 15 minutes and one of 45 hours. During the 45-hour shutdown the section was isolated by valves. The other section was subjected to 12 simulated shutdown cycles, the average cycle 
consisting of 25.4 hours exposure to $349.5^{\circ} \mathrm{F}$ geofluid flow, a 4.2 -hour pressurized cooldown period, then 56.2 hours in which the chamber was open to the air and the coupons were partially filled with geofluid.

Upon completion of the test, al1 36 specimens were covered by tenacious deposits, determined by energy dispersive spectroscopy to be iron with a trace of calcium, indicating that the deposits were mostly iron oxides. It was concluded that these deposits came from elsewhere in the system. Fxamination of resultant weight-loss data showed no statistically significant weight-1oss during the test. Even if the worst case were assumed--that the coupon with the greatest weight-1oss (an A1loy 29-4 coupon) 1ost a11 of its weight from the interior surface-then the calculated corrosion rate would be on1y 0.045 mpy.

Stereomicroscopic, metallographic, and scanning electron microscopic examination showed no evidence of pitting, crevice corrosion, stress corrosion cracking, or preferential attack of the base metal, the weld metal or the heataffected zone. There was no statistically significant difference between the performances of the two alloys. These test results support the selection of either alloy as highly suitable for geofluid/hydrocarbon heat exchangers when this or similar geofluid is used. The chromium and molybdenum contents of the alloys indicate that they probably could withstand a higher chloride concentration. However, much longer exposure than this test, perhaps even years duration, would be required to completely verify the corrosion performances of these alloys [E11is and Anliker 1982]. 
The heat rejection system of any geothermal power plant-with the exception of atmospheric backpressure discharge steam systems--contains one or more large condensers which condense the working substance, either steam or organic vapor. The heat rejection system also includes a variety of smaller heat exchangers which provide cooling for service streams such as lubrication oil and hydrogen for large generators.

Almost al1 geothermal steam plants operational today, whether the steam is derived form a vapor-dominated resource or by flashing from a liquiddominated resource, used direct contact condensers to provide vacuum at the turbine exhaust [E11is and Conover 1981]. However, a11 domestic geotherma1 steam plants commissioned since 1980 have had surface contact condensers as a part of their hydrogen sulfide abatement system [DiPippo 1980], and it is likely that most if not all future plants will be so equipped.

Some leakage of steam condenser tubes may be acceptable. Though it would degrade turbine efficiency by increasing exhaust backpressure and would also impair the hydrogen sulfide abatement process, a small leakage would probably not force a plant outage.

Most near-term geothermal binary plants will also have surface contact condensers. The materials problems facing these condensers are also more severe since 1 ittle if any leakage of working substance can be tolerated. In addition these plants will not have available as cooling water makeup the large quantities of high quality condensate produced by geothermal steam plants, leading to use of poorer quality water and increased corrosion and fouling potential. 
Plants with steam condensate available for cooling water make-up have an abundant supply of good quality water for this purpose. The quality of the water circulated through the condensers will be dependent on the cycles of concentration in the cooling tower operation, and on the amounts of dust, fumes, insects, and other atmospheric pollutants washed from the air that passes through the cooling towers. Table 5-1 presents a sampling of cooling water chemistries from four geothermal steam power plants. These analyses are probably typical of the ranges of cooling water chemistry which are likely to be encountered at such plants.

At Cerro Prieto there was extensive corrosion on the water-side of the original aluminum oil cooler tubes of Units 1 and 2 and after fifteen days operation, a 1 arge percentage were perforated and al1 showed signs of pitting. The oil cooler tubes were replaced with Type 304. After several months, pitting of some of these tubes was also observed. The primary cause appears to be occlusion cell corrosion and corrosion by microorganisms during periods of shut down. Current practice calls for draining and careful drying of the oil coolers during shut down. Later units were tubed with titanium [E11is and Conover 1981 ].

Originally the tubes of the hydrogen cooler were also aluminum. Like the oil cooler tubes they were-severely attacked after 15 days of operation, but due to their thicker walls, none were perforated. These tubes were replaced with titanium which showed no signs of corrosion in four years of operation [E11 is and Conover 1981].

The surface condensers at The Geysers are tubed with Type 304 stainless steel. Definitive data on the corrosion performance of these tubes are not available. However, prior experience with stainless steels in cooling systems at The Geysers indicates that pitting and crevice corrosion may be a problem. Long-term (more than 550 day) corrosion tests in circulating cooling 
TABLE 5-1. EXAMPLES OF COOLING WATER CHEMISTRY FROM GEOTHERMAL POWER PLANTS USING STEAM CONDENSATE WITHOUT HYDROGEN SULFIDE ABATEMENT AS COOLING WATER MAKE-UP (ppm except $\mathrm{pH}$ )

\begin{tabular}{|c|c|c|c|c|}
\hline & $\begin{array}{c}\text { The } \\
\text { Geysers, } \\
\text { California }\end{array}$ & $\begin{array}{l}\text { Cerro } \\
\text { Prieto, } \\
\text { Mexico }\end{array}$ & $\begin{array}{c}\text { Lardere11o, } \\
\text { Italy }\end{array}$ & $\begin{array}{l}\text { Ahaachapan, } \\
\text { E1 Sa1vador }\end{array}$ \\
\hline $\mathrm{pH}$ & $\sim 7$ & $\sim 7$ & $6.7-7.8$ & $6.8-8.4$ \\
\hline Total Alka1inity (as $\left.\mathrm{CaCO}_{3}\right)$ & 482 & - & - & $15-205$ \\
\hline Sulfate & 229 & - & $50-300$ & $122-168$ \\
\hline Chloride & $<1.0$ & $50-60$ & $1-75$ & $21-52$ \\
\hline Snlfide & $\sim 1$ & - & - & -- \\
\hline Ammonia & $53-339$ & - & $190-310$ & - \\
\hline Silica & 1.5 & - & Trace & $1.7-3.6$ \\
\hline Ca1cium & $<1$ & - & $2-4$ & $2.5-7.7$ \\
\hline Magnesium & $<1$ & - & $0.2-0.5$ & $0.1-0.3$ \\
\hline TDS at $220^{\circ} \mathrm{F}$ & 111 & - & $500-800$ & -- \\
\hline
\end{tabular}

- data not available.

Source: E11is and Conover 1981 
water at this site showed that Type 304 was subject to some pitting, at an annualized rate of $1.1 \mathrm{mpy}$, as we11 as crevice corrosion. Type 316 showed no localized corrosion.

The corrosivity of the cooling water at The Geysers is increased because ppm concentrations of ferric ion are added to catalyze the oxidation of sulfide in the condensate. This is the principal method of hydrogen su1fide abatement in Units $1-12$, which have direct contact condensers. Though the later units have surface contact condensers and stretford Process systems for hydrogen sulfide removal, some hydrogen sulfide remains in the condensate and enters the cooling water stream. Therefore, some ferric ion is also added to the cooling water of the units with surface contact condensers. With the addition of about $30 \mathrm{ppm}$ ferric ion, the pitting corrosion $x$ ate for Type 304 increased almost ten-fold, for an annualized rate of 9.3 mpy. The rate of penetration increased with time. Again, Type 316 did not show pitting [E11is and Conover 1981 ].

The onset of pitting and crevice corrosion of stainless steels in aerated waters is a function of the chromium and molybdenum content of the alloy and the chloride content and temperature of the water. Increases of chromium and molybdenum increase the threshold temperature above that at which pitting or crevice corrosion occurs. Increasing chloride content lowers the threshold temperature. In the range 4 to 8 , pH probably has 1 ittle effect on the threshold temperature, although an acidic pH favors more numerous pits with more rapid penetration rates.

Once pitting conditions have been obtained, initiation typically occurs within hours. Once this has occurred, an autocatalytic process (pitting) is established and in many cases will be self-sustaining even when process conditions moderate. For this reason, the upper 1 imits of temperature and chloride to which a component will be exposed are of particular interest. Pit penetration rates are extremely difficult to predict, since they may 
increase or decrease with time, and corrosion allowances cannot be reliably defined. Fspecially for thin walled components, such as heat exchanger tubes, a go/no-go pitting criteria may be prudent for material selection.

The threshold temperature for localized corrosion of Type 304 and Type 316 as a function of chloride concentration was explored by Efird and Mo11er [1978]. Figure 5-1 shows the results of their work. Localized corrosion may initiate if the upper limits of cooling water chloride and temperature are above the diagona 1 ines, but are not 1 ikely to initiate if all operating conditions 1 ie below these lines. This figure indicates the conditions which may initiate pitting or crevice corrosion, but does not predict the severity of attack.

Another potential concern with austenitic (AISI 300 series) stainless steels is chloride stress corrosion cracking (chloride-SCC). The phenomenon is a function of $\mathrm{pH}$, chloride concentration, oxygen concentration, and temperature. Figure 5-2 shows the threshold temperature for chloride-SCC of Type 304L stressed near the yield point as a function of ch1oride concentration in air-saturated sodium chloride brine. It indicates that the threshold temperature for chloride-SCC of Type 304L at yield stress is greater than $140^{\circ} \mathrm{F}$. However, tests at Wairakei [E11 is and Conover 1981] set the threshold for Type 304 under plastic stress at $121^{\circ} \mathrm{F}$. Type 316 with its increased molybdenum content will have a higher chloride-SCC threshold temperature than Type 304, while Type $317 L M$ is resistant to chloride-SCC in the wick test, a relatively severe test [E11is and Conover 1981].

If Type 304 and Type 316 axe judged not to have sufficient probable corrosion resistance, variety of "super ferritic" stainless steels are commercially available as alternatives. These include Allegheny-Ludlum Alloys 294, 29-4-2, and 29-4C, as well as SeaCure 26-3. These alloys are high1y resistant to chloride-SCC. Because of their increased chromium and molybdenum (the first two numbers in the designation reflect the percent $C r$ and $M o$ ), they are 
Temperature $\left({ }^{\circ} \mathrm{F}\right)$

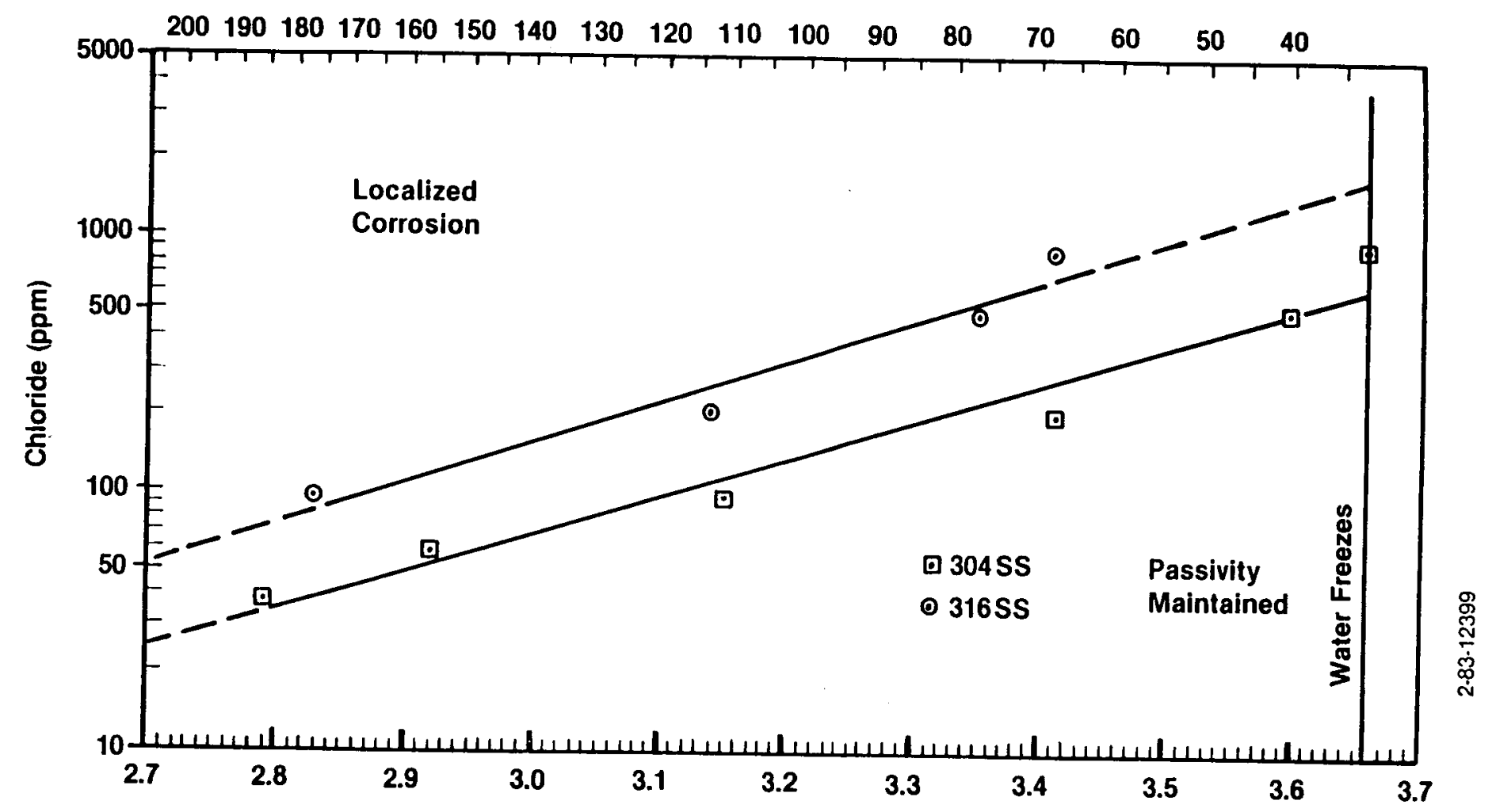

Reciprocal Absolute Temperature $\left({ }^{\circ} \mathrm{K}^{-1} \times 1000\right)$

Figure 5-1. Chloride Required to Produce Localized Corrosion of Type 304 and Type 316 as a Function of Temperature

[Data from Efird and Moller 1978] 


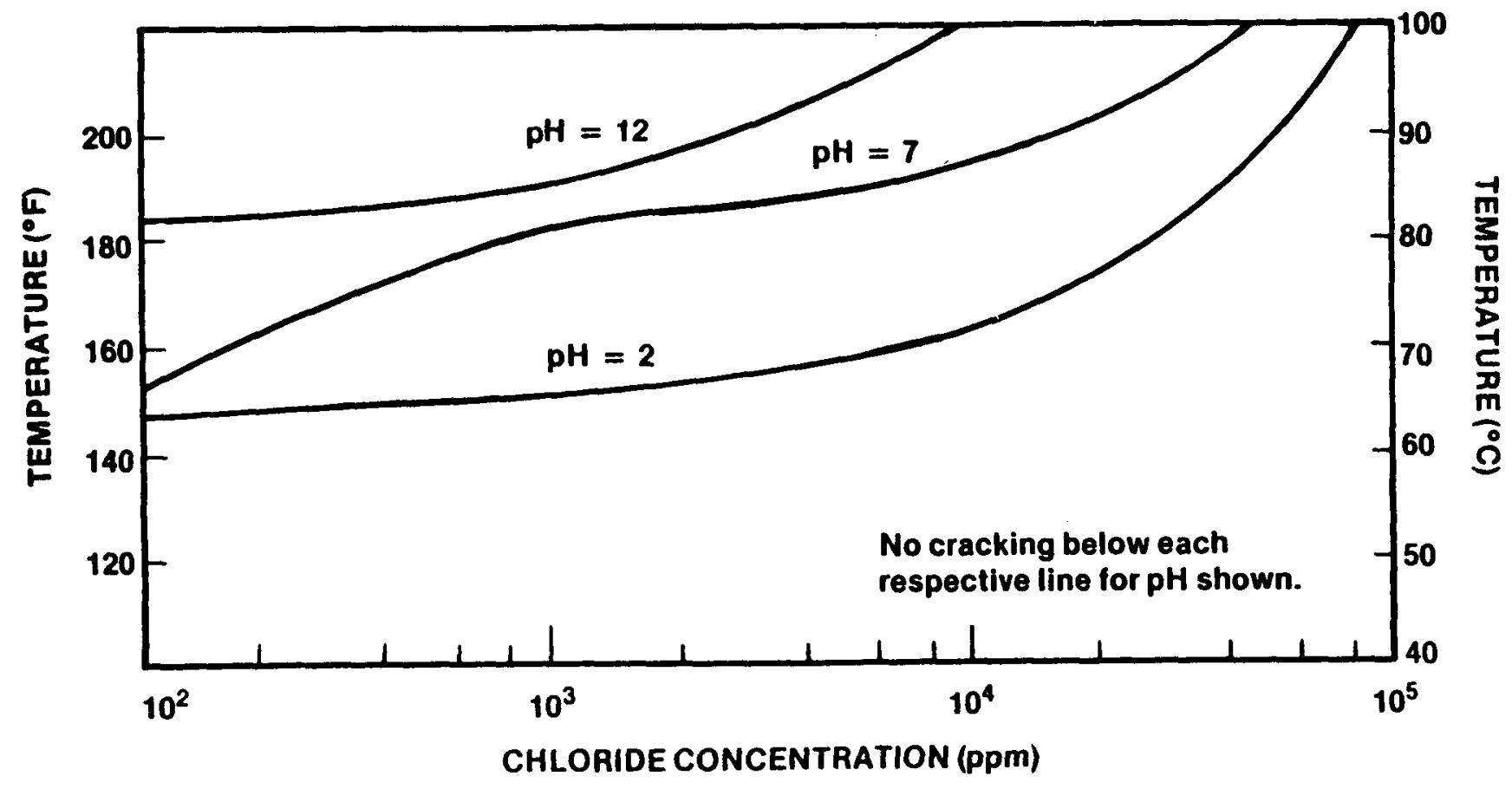

Figure 5-2. Effect of pH, Chloride Content, and Temperature on the Stress Corrosion Cracking of Type 304 Stainless Steel under Residual Weld Stresses. As-Welded Tube Specimens; Sodium Chloride Dissolved in Water Under Air; Exposure Time Op to 8000 Hours (E11is and Conover, 1981). 
much more resistant to localized corrosion than are Type 304 and Type 316. They contain 1ittle or no nickel, and as of 1982 their cost was competitive with Type 304. Titanium would provide another excellent alternative.

\subsection{Geothermal Binary P1ants}

Geotherma1 binary plants, and others which do not have access to large amounts of stean condensate for cooling water make-up, will have to use whatever water is available for cooling water. Most such plants will be 10cated in arid and semiarid regions, where vigorous competition for water-use rights is likely. Therefore these plants are likely to be forced to use poor quality water for cooling. In some cases, such as Raft River, it was necessary to use treated cooled geothermal fluid for this purpose.

The Raft River binary plant is a 5 MWe (net) daal boiling cycle geothermal power plant intended to demonstrate the feasibility of the binary cycle for intermediate temperature resources. The plant was initially intended to be a simple thermal loop with an expansion device simulating a turbine. Duxing the design phase the plant was modified to incorporate a dual entry turbogenerator.

The power cycle is dual boiling with isobutane as the working fluid. Geofluid at $290^{\circ} \mathrm{F}$ enters a series of four shell and tube heat exchangers. In one pair, isobutane is preheated, vaporized at $240^{\circ} \mathrm{F}$ and 381.6 psia, then routed to the high pressure inlet of the turbine. Jn the other two heat exchangers--supplied with geofluid from the first pair-isobutane is preheated, vaporized at $180^{\circ} \mathrm{F}$ and $203.0 \mathrm{psia}$, then routed to the low pressure inlet of the turbine.

The isobutane from the turbines is condensed in a single $57,000 \mathrm{ft}^{2}$ carbon steel tubed condenser. The cooling water system was designed to use about $350 \mathrm{gpm}$ surface water for make-up [Suciu and Miller 1980]. Partway 
through construction of the plant, after the major carbon steel components had been delivered, it became necessary to use cooled geothermal water for cooling tower make-up.

Since this water contains about 700-1000 ppm chloride, $65 \mathrm{ppm}$ sulfate, 60-120 ppm oalcium and 140-155 ppm $\mathrm{SiO}_{2}$, significant water treatment probloms were encountered whon the cooling water was aerated and concentrated in cooling torer operation. The intial water treatment system was designed to use dolomitic 1 ime ( 58 wt percent $\mathrm{Ca}(\mathrm{OH})_{2}$ and 37 wt percent $\mathrm{MgO}$ ) to remove s1110a and chromate-zinc system for corrosion contro1. In addition, a CraneCochrane DNIPAC I chomical destruct unit, using sulfuric acid, sodiom bisulfite, and 1ime, was to be used to remove chromium and zinc from the blowdown water prior to its discharge. The initial make-up system was intended to reduoe the incoming ailica level to $10-15 \mathrm{ppm}$ to provide make-up required for ton oyoles of concentration. The system could treat $346 \mathrm{gpm}$ of make-up water and $32 \mathrm{gpm}$ of blowdown water.

Jar test on the precipitation of silica from Raft River geothermal water showed that reduction of silica did not occur to the extent predicted. It was concluded that the data upon which the 5 MW(e) water treatment system had boon designed codd not be extrapolated to predict precipitation of silica frow geothermal water; therefore, several other chemicals were tested to detormine their ability to precipitate silica.

In addition, coupon corrosion tests showed that though the chromate corrosion inhibitor, at lovels of about $400 \mathrm{ppm}$ chromate (as $\mathrm{Cr}^{+}$), controlied the "uniform" corrosion of carbon steol to about 1-2 mpy, serious pitting at about 1-2 mils/weok did occur [Suciu and Millex 1980]. An extreme value analysis showed that the worst pits in the condenser wonld be 5.4 to 7.7 mils deep after one week [E11is 1980]. Since the condenser tube walls were only 85 mils thick, no level of chromate could suppress pitting in the acrated 10,000 ppm chlorido reolronlating cooling water, and serious problem existed. 
A water treatment development program to control the silica in the make-up water, and to develop a chromate-freo phosphate-based treatment system to control the pitting corrosion of the carbon steel condenser tubes, was undertaken. The final result of this effort was the treatment program summarized in Tab1e 5-2.

The condenser was cleaned and passivated in $\mathrm{July} 1980$ with the solutions indicated in Table 5-2. Phosphoric acid was used. Inspection after the second of two attempts showed a generally good film with a few rust spots. The condenser was placed in wet lay-up, filled with passivating solution, from Angust into October 1980. In October the passivating solution was circulated for one week, then drained. Inspection showed a good film with healing of the rust spots noted in Angust. The condenser was dried and kept under nitrogen blanket [Suciu and Wikoff 1981] until plant start-up in the fa11 of 1982 .

Not long after the plant start-up, an upset lowered the cooling water pH to 4. A $r$ ise in the iron content of the cooling water indicated that the passivation layer had been destroyed. Two attempts were required to repassivate the condenser. The plant then operated from mid-January to midJune 1982. Calculations based on the iron content of the condenser inlet and outlet streams indicated a corrosion of 2-4 mpy, assuming only uniform corrosion. No tube samples were obtained after the plant was shut down in June, so the ability of the treatment program to control pitting of the carbon steel tubes cannot be verified [Suciu 1983].

It is clear, however, that the treatment program is not an ideal solution. The chemical requirements are large and therefore costly, and the system is made inherently sensitive to control upsets which would force several-week-1ong shutdowns for cleaning and repassivation of the condenser.

EG\&G [Suciu and Wikoff 1982] also tested a number of alloys to determine their corrosion resistance in high-saline aerated water such as that found in ovaporative cooling systems which use geofluid for makeup. Because 
TABI,F 5-2. SUMMARY OF FINAL WATFR TREATMENT FOR THE

RAFT RIVER COOL. ING WATFR I.OOF

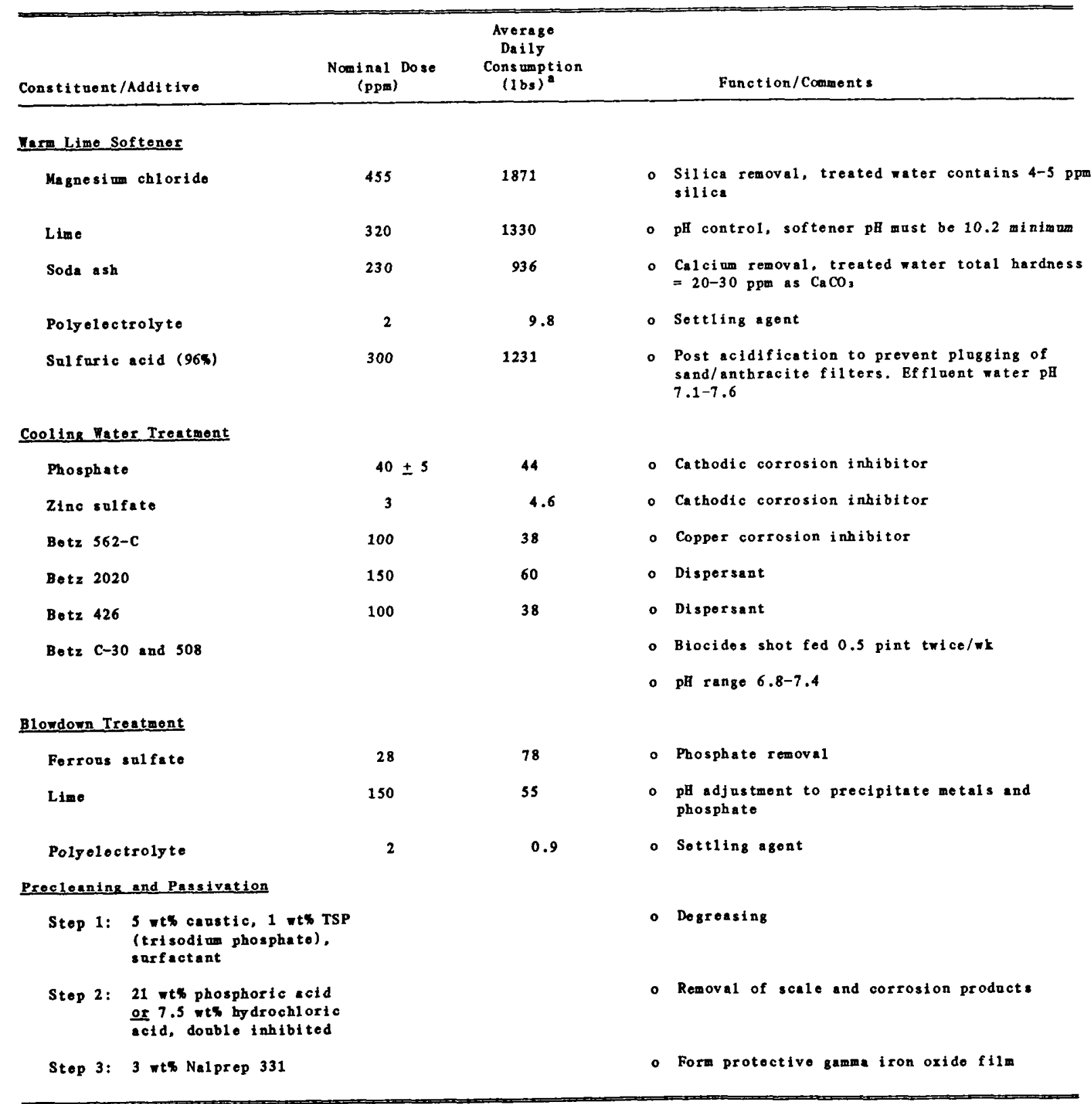

Basod on nowinal make-op and blow-down rates of 346 and $32 \mathrm{spa}$.

Sonrce: Sucin and thoff 1981. 
the geofluid is concentrated 2 to 10 times in such systems, Raft River geothermal water was softened with warm 1 ime and magnesium chloride, then spiked with varying amounts of sodium chloride for these tests.

In preliminary tests, coupons of the various metals were exposed in aerated spinner jars for about 30 days at a constant temperature of $95^{\circ} \mathrm{F}$. The $p H$ was maintained at 6.8 to 7.2 . Chloride concentration was varied from 10,000 to $200,000 \mathrm{ppm}$. Results of these preliminary trials are reported elsewhere [Smith and E11 is 1983].

Those metals which showed good corrosion resistance in the spinner tests and which were considered moderately priced were tested further in pilot cooling tower tests. The test units were designed to simulate actual operating conditions. The cooling water circulation rate was maintained at 5 fps on the she11 side of a she11-and-tube heat exchanger; geothermal water cooled to $140^{\circ} \mathrm{F}$ flowed on the tube side. Flow was controlled so that the heat exchanger effluent was maintained at $95^{\circ} \mathrm{F}$. The chemistry of the circulating water is given in Table 5-3. The results are given in Table 5-4.

The materials and their uses as recommended by Suciu and Wikoff [1982] at the conclusion of these tests axe given below (the corrosion allowance used in the tube 1 ife estimate was not reported):

- Ferritic stainless steols (such as SeaCure 26-3 and the $29 \mathrm{Cr}-4$ Mo alloys) used for condenser tubing have an expected 1 ife of 47 to 70 years.

- The cupronickel alloys used as condenser tubing material in high-salinity water have an expected 1 ife of 22 to 40 years. The use of a copper inhibitor may be required.

- Altbough several austenitic stainless steels and nicke1based alloys exhibited good corrosion resistance, preliminary cost comparisons indicate that these metals are more expensive than the ferritic materials.

- Carbon steel is adequate for shell material if those portions exposed to the brine (water boxes) are organically coated or clad with a corrosion-resistant material. 
TABLE 5-3. TYPICAL ANALYSIS OF THE CIRCULATING WATER IN PILOT COOLING TOWER CORROSION TESTS

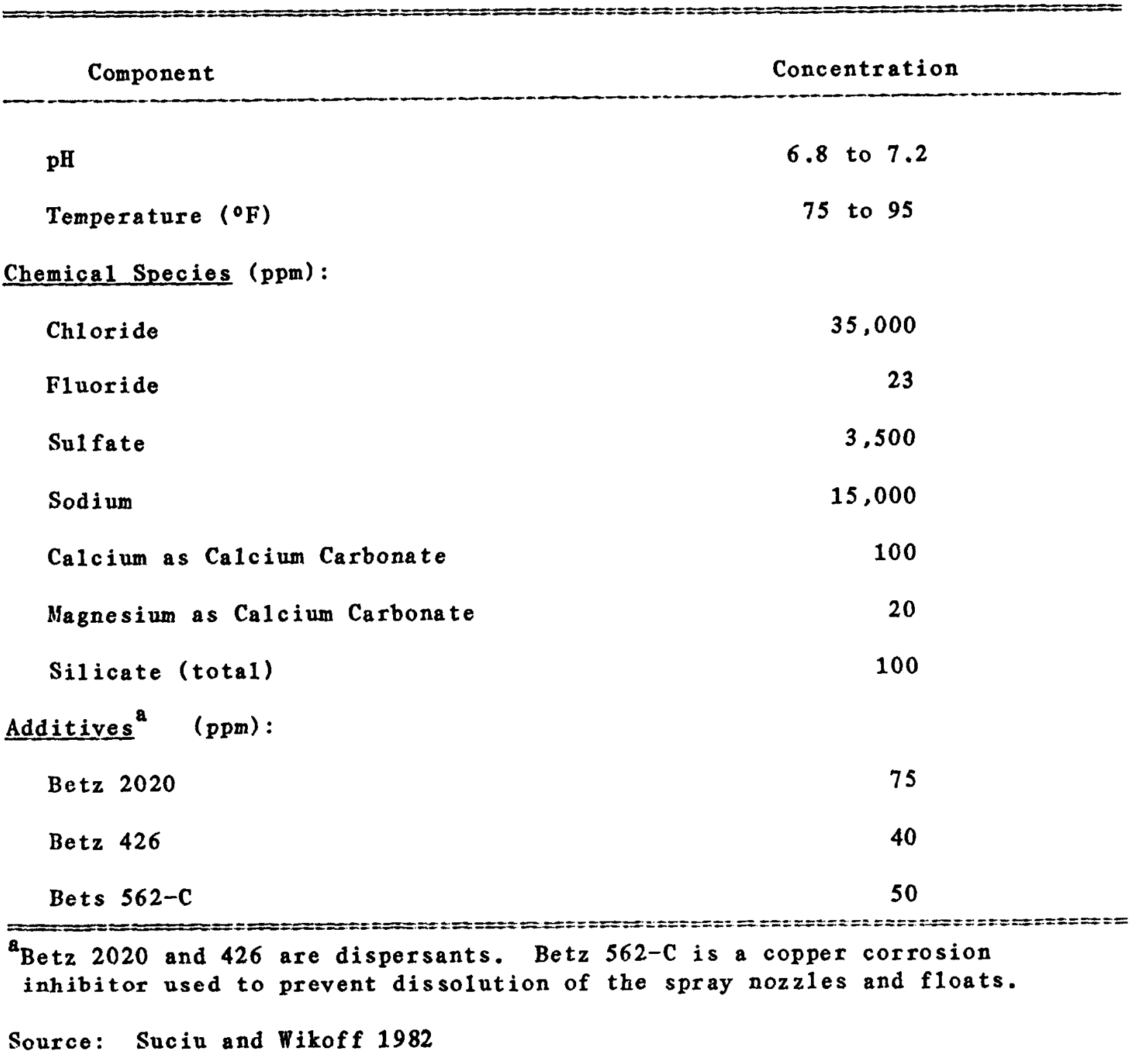


TABLE 5-4. RESULTS OF THE PILOT COOLING TOWER TESTS AT RAFT RIVER, ID

\begin{tabular}{|c|c|c|c|}
\hline Al1 oy & $\begin{array}{l}\text { Test } \\
\text { Duration } \\
\text { (months) }\end{array}$ & $\begin{array}{c}\text { Corrosion Rate } \\
\text { (mpy) }\end{array}$ & Comments \\
\hline Seacure $26-3$ & 10 & 0.17 & $\begin{array}{l}\text { No pitting or crevice } \\
\text { corrosion. No evident } \\
\text { change in surface. }\end{array}$ \\
\hline $70 / 30$ Cupronicke 1 & 10 & 0.19 & $\begin{array}{l}\text { No pitting or crevice } \\
\text { corrosion. No evident } \\
\text { change in surface. }\end{array}$ \\
\hline 90/10 Cupronicke 1 & 4 & 0.30 & $\begin{array}{l}\text { Dealloying and pitting } \\
\text { (depth not quantified). }\end{array}$ \\
\hline Admiral ty Brass & 6 & 0.25 & Dea11 oy ing \\
\hline Carbon Stee1 & 4 & 4.0 & $\begin{array}{l}\text { Crevice and pitting } \\
\text { corrosion. Pits }>0.25 \text { in. } \\
\text { dia. and }>30 \text { mils deep. }\end{array}$ \\
\hline $\begin{array}{l}12 \mathrm{Cr} \text { Stainless } \\
\text { Steel }\end{array}$ & 6 & 1.76 & $\begin{array}{l}\text { Crevice and pitting } \\
\text { corrosion. Pits }>0.25 \text { in. } \\
\text { dia. and }>50 \text { mils deep. }\end{array}$ \\
\hline Allegheny $6 x$ & 4 & 0.60 & $\begin{array}{l}\text { Pitting corrosion } \\
\text { (scattered pits } 0.25 \text { in. } \\
\text { dia. and } 16 \text { mils deep). }\end{array}$ \\
\hline $\begin{array}{l}\text { A1 legheny-Lud1 um } \\
29-4 C\end{array}$ & 4 & 0.29 & $\begin{array}{l}\text { No pitting or crevice } \\
\text { corrosion. No evident } \\
\text { change in surface. }\end{array}$ \\
\hline Mone 1400 & 4 & 0.63 & $\begin{array}{l}\text { Pitting corrosion } \\
\text { scattered, pits visible } \\
\text { with low magnification } \\
\text { (no depth data) }\end{array}$ \\
\hline 7-A1 Bronze & 4 & 1.08 & Severe general corrosion \\
\hline Ferralium 255 & 2 & 0.49 & $\begin{array}{l}\text { No pitting or crevice } \\
\text { corrosion. No evident } \\
\text { change in surface. }\end{array}$ \\
\hline
\end{tabular}

Source: Suciu and Wikoff 1982 
- Carbon steel piping should be coated or else replaced with plastic pipe.

Despite their good performance in this test, considerable caution should be used in applying the results to cupronickels at other sites. The Raft River geofluid contains less than 1 ppm hydrogen sulfide or ammonia. At locations where the make-up water contains significant amounts of these species--or where they may enter the cooling water via absorption from the atmosphere in the cooling towers, the performance of cupronickels may be much worse. For example, seawater heat exchanger experience has shown that hydrogen sulfide concentrations of only 7 ppb can cause severe pitting of these alloys [E1 1 is and Conover 1981].

Fven where surface water is used for cooling water make-up, problems with water treatment have occurred in geothermal operations. During geofluid/ hydrocarbon evaporator tests at East Mesa (described in Section 2) the hydrocarbon condensers were cooled with treated surface water in a cooling tower system. The make-up water had a TDS of $1400 \mathrm{ppm}$ [Silvester and Doy1e 1982], and is presumed to have come from a nearly Imperial Irrigation District (IID) cana1. Table 5-5 is a typical analysis of that water, which originates from the Colorado River. The number of cycles of concentration are not known.

The make-up water was treated by the addition of 600 ppm phosphonates and addition of sulfuric acid to maintain pH 7 . Scaling of the condenser/subcooler was a continual problem. The condenser was designed to operate at high condensing pressures ( 245 psia), and high condensing temperatures $\left(\sim 200^{\circ} \mathrm{F}\right)$. This was done to reduce the head requirements of the hydrocarbon recirculation pump. Since the higher condensing pressure means a higher condensing temperature, a smaller condenser could be built for the original heat load. However, this resulted in high tube wall temperatures and concomitantly a larger temperature rise $\left(\sim 30^{\circ} \mathrm{F}\right)$ in the cooling water than is common practice $\left(\sim 10-15^{\circ} \mathrm{F}\right)$. These factors exacerbated the fouling problem since most chemical treatments are designed for cooler water temperatures [Silvester and Doyle 1982] and adequate control of scaling was never obtained. 
TABLE 5-5. TYPICAL IID IRRIGATION WATER CHEMISTRY

\begin{tabular}{|c|c|}
\hline Component & Concentration (ppm except pH) \\
\hline pH (field) & 8.2 \\
\hline Chloxide & 200 \\
\hline Sulfate & 335 \\
\hline Bicarbonate & 140 \\
\hline Carbon Dioxide (Total) & 16.4 \\
\hline Hodrogen Sulfide & $-\infty$ \\
\hline Amonia & 0.03 \\
\hline Siltea & $-\infty$ \\
\hline Calciun & 102 \\
\hline Magnesium & 22 \\
\hline TDS & 1052 \\
\hline
\end{tabular}

Source: F1uor 1981 
Measurements of the fouling factor $\left(R_{f}\right)$ as a function of time were made during $198 \mathrm{hrs}$ of testing. During this time, three different hydrocarbons--commercial isobutane, nomina1 $90 / 10$ isobutane/isopentane, and nominal $80 / 20$ isobutane/isopentane--were circulated on the hydrocarbon side. From the composite data, it was found that:

$$
\begin{aligned}
& R_{f}=0.0005+1.03 \times 10^{-5} t \\
& \text { where } R_{f}=\text { fouling factor in }(h r)\left(\mathrm{ft}^{2}\right)\left({ }^{\circ} \mathrm{F}\right) / \mathrm{Btu} \\
& t=\text { elapsed time in hours. }
\end{aligned}
$$

The correlation coefficient was $>.99$ indicating extremely good fit of the above equation to the data. This indicates that with the water treatment used, a design fouling factor of $0.002(\mathrm{hr})\left(\mathrm{ft}^{2}\right)\left({ }^{\circ} \mathrm{F}\right) / \mathrm{Btu}$ would be reached in only about 145 hours. After one year the fouling factor would be about $0.091(h r)\left(f t^{2}\right)\left({ }^{\circ} F\right) / B t u$. 
An1iker, D.M. and P.F. F11 is, 1982. Failure Analysis Report: Heat Exchanger Tubes, Geotherma1 Binary Power P1ant, Magma Electric Company, East Mesa, Ca1ifornia. DOE Contract No. AC03-81SF11503, DCN 82-212-01133, Radian Corporation, Austin, Texas, May.

Bott, T.R. and J.S. Gudmundsson, 1978. "Rippled Silica Deposits in Heat Exchanger Tubes," 6th International Heat Transfer Conference (Vo1. 4), Toronto, Canada.

Rott, T.R. and J.S. Gudmundsson, 1979. "The Problem of Fouling in Utilization of Geothermal Energy," International Conference on Future Energy Concepts.

namb1y, B.W., 1978. "Heat Exchanger Design for Geothermal Power Flants" 13th Intersociety Energy Conversion Engineering Conference, Society of Engineering Conference, Society of Automotive Engineers, November.

DiPippo, R., 1980. A For1dwide Survey of the Design and Operation of Geothermal Power Plants, NTIS Pub Code D0E/RA/28320-1, Brown University, Providence, Rhode Island, January.

Efird, K.D. and G.E. Mo11er, 1978. "Electrochemical Characteristics of 304 and 316 Stainless Steels in Fresh Water as Functions of Ch1oride Concentration and Temperature." Paper 87, Corrosion/78. Houston, TX, 610 March.

F11 is, P.F., 1980. Serious Pitting Hazard in the Raft River 5 MW(e). Geotherma1 Power P1ant I sobutane Cooling Loop. DOE Contract No. DE-AC0279ET27026, DCN 80-212-003-17. Radian Corporation, Austin, TX, February. 
E11is, P.F. and D.M. An1iker, 1982. Corrosion Test Report: Simulated

Heat Exchanger Tubes, DOE Geothermal Test Facility, East Mesa,

Ca1ifornia, DOE Contract AC03-81SF11503, DCN 82-212-011-42, Radian

Corporation, Austin, Texas, November.

F11 is, P.F, and M.F. Conover, 1981. Material Selection Guidelines for

Geothermal Energy Utilization Systems. NTIS Pub Code DOE/RA/27026-1, Radian Corporation, Austin, Texas, January.

Fe1singer, D.E., 1973. Geotherma1 Field Test: Heat Exchanger Eva1uation, NTIS Pub Code DOE/ET/28443-T5, San Diego Gas and Electric Company, San Diego, California, July.

Fischer, P., J.W. Suitor, and R.B. Ritter, 1975. "Fouling Measurement Techniques," Chemical Engineering Progress, Vo1. 71, No. 7, July.

F1uor 1981. Project Design Guide, Heber Geotherma1 Binary Demonstration Project (Rev. 3), SAN/RA50239-FPS-001, F1uor Power Services, Irvine, California, October.

Ho1t 1978. Geothermal Heat Exchanger Test at Heber, California, EPRI ER-572. The Ben Holt Company, Pasadena, California, August.

Ho1t, B., 1982. Personal communications with Peter E11is, September.

J.S. Gudmundsson, 1979. "Deposition of Silica From Geothermal Waters on Heat Transfer Surfaces." Desalination, 28, 125-145.

Lombard, G.I., 1975. Test and Evaluation of a Geotherma1 Heat

Exchanger. NTIS Pub Code PB-247 218, San Diego Gas and Electric Company, San Diego, Ca1 ifornia, September. 
Meiran (PE), P.F., 1982. (Consultant, Metallurgy \& Corrosion) Materia1s Selection for the Brine Hydrocarbon Heat Exchangers and the Hydrocarbon Condensers, SAN/RA 50239-FPS-0004, F1uor Power Services, Irvine, CA, Apri1.

Miller, R.L., 1977. Resu1ts of Short-Term Corrosion Evaluation Tests at Raft River, TREE-1176, EG\&G Idaho, Inc., Idaho Falls, ID, October.

Shannon, D.W., 1977. Corrosion of Iron Based Alloys Versus Alternate Materials in Geotherma1 Brines, Interim Report Period Ending October 1977. NTIS Pub Code PNL-2456, Battelle Pacific Northwest Laboratory, Richland, WA, November.

Shannon, D.W., 1978. Brine Chemistry and Combined Heat/Mass Transfer (Vo1. 1) EPRI ER635, Battelle Pacific Northwest Laboratory, Richland, Washington, January.

Shannon, D.W., R.P. E1more, and D.D. Pierce, 1981. Monitoring the Chemistry and Materials of the Magma Binary Cycle Generating Plant. NTIS Pub Code PNL-4123. Rattelle Pacific Northwest Laboratory, Richland, Washington, October.

Silvester, L.F. and P.T. Doyle, 1982. Analysis of Field Performance Data on She11-and-Tube Heat Exchangers in Geotherma1 Service, Pub Code LBL-14160, Lawrence Berkeley Laboratory, Berkeley, CA, March.

Smith, C.S. and P.F. F11is, 1983. Addendum to Material Selection Guide1ines for Geotherma 1 Energy Utilization Systems, NTIS Pub Code DOE/RA/27026-2, Radian Corporation, Austin, Texas, May.

Suciu, D.F., 1983. EG\&G. Personal communications with Peter E11is, Apri1. 
Suciu, D.F. and P.M. Wikoff, 1981. Corrosion Testing of Carbon Steel in Aerated Geotherma1 Brine. DOE Contract No. AC07-76ID 01570. EG\&G Idaho, Inc., Idaho Falls, ID, February.

Suciu, D.F. and P.M. Wikoff, 1982. An Evaluation of Materials for Systems Using Cooled, Treated Geotherma1 or High-Saline Brines. DOE Contract No. DE-AC07-76ID01570. EG\&G Idaho, Inc., Idaho Fa11s, ID, Sept ember.

Suciu, D.F. and R.L. Mil1ex, 1980. Short-term Pilot Cooling Tower Tests. DOE Contract No. DE-AC07-76ID01570. EG\&G Idaho, Inc., Idaho Fa11s, ID, January.

Syrett, B.C., D.D. MacDona1d, H. Shih, and S.S. Wing, 1977. Corrosion Chemistry of Geotherma 1 Brines, Part 1: Low Salinity Brines, NSF Grant No. AER 76-00713, SRI No. 5308, Stanford Research Institute, Men1o Park, California, Sept ember.

Underhi11, G., 1982. Camas Associates. Personal communications with Peter E11is, Novenber.

\U.S. GOVERNMENT PRINTING OFFICE: $1984-746-08$ V 2292 REGION NO. 4 